\title{
Relationship Management Maturity
}

\subsection{The Design and Introductory Steps of RM Maturity Conceptualization}

When building a theory, two strategies are generally available to management scholars: the interpretative-symbolistic contextualization and the neo-positivistic functionalistic-systemic idealization strategy (Czakon 2015). In the contextualization strategy, the inference and explanation are an interrelated, context-dependent process. The researcher is an active "interrogator of the data" who seeks to find the best theoretical explanation based on empirical evidence and preferred epistemic virtues (EasterbySmith et al. 2012; Strauss and Corbin 1998). In consequence, the primary mode of reasoning is induction, and the developed theory is grounded in empirical data (Charmaz 2004).

The idealization strategy assumes the opposite direction of scientific inquiry. By appealing to deductive reasoning, theoretical propositions are formed and then empirically verified in search of objective, universally observable causal rules (Czakon 2015). These inductive arguments are reinforced by normative guidelines. The latter, in turn, rely on the hypotheses which were earlier analytically derived from the theory (Sprenger 2011). A specific product of such a hypothetico-deductive (H-D) theory confirmation method is so-called ideal organizational types and profiles. Ideal types are complex theoretical constructs, which describe a model 
organization that, if it existed, would enjoy the highest possible values of dependent variables. Ideal profiles, in turn, describe real organizations resembling different variants of the given ideal type (Doty and Glick 1994). According to H-D logic, if empirical data give credit to theoretical generalizations represented by the ideal type reflected in its associated profiles, the underlying theory can also be credited and qualified as valid (Ketokivi and Mantere 2010).

The theoretical ideal type resembles the notion of 'maturity', which, in general, can be understood as the state of being complete/perfect in implementing, or being ready to implement, something (e.g. a given strategic approach to management; Wendler 2012). Modelling of organizations' maturity has been applied in various ways, especially in project, process and quality management (Lichtarski 2015; Rosemann and de Bruin 2005). A good example is the ISO certification system or the Capability Maturity Model for software (CMM). The latter was developed in the period 1986-1991 by the Software Engineering Institute at Carnegie Mellon University to help organizations (firms and US governmental bodies) in successful deployment of their software projects (Paulk et al. 1993).

CMM is a widely adopted underlying framework in Business Process Management (BPM) research. It is unsurprising then that the very concept of maturity has also been extensively developed by BPM scholars (Mettler 2011; Röglinger et al. 2012; Tarhan et al. 2016). According to this research tradition, maturity models help to assess at what development stage an organization is situated by defining and arranging key descriptive management-related concepts and constructs. Further on, maturity models contain some prescriptive elements. Finally, they are used as a platform for disseminating research findings to the broader business audience (Kazanjian and Drazin 1989).

Clearly, the position of RM mid-range theory between R-A theory and empirical research amplifies the need for an unambiguously defined supporting RM maturity model (grounded in both theory and practice) that would demonstrate the identity of companies truly implementing the relational business model. However, the wide application of maturity models has also raised some criticism, especially highlighting their focus on a predefined sequence of maturity levels towards an imagined 'end state' and neglecting equifinal maturation paths (De Bruin et al. 2005). In response to this criticism several guidelines for the development of a successful 
maturity model have been proposed, including the following (Pöppelbuß and Röglinger 2011; Rosemann 2006):

- offering clear information about the model application domain, the proposed constructs and their theoretical underpinning;

- defining its key success factors to a high level of granularity (providing concrete answers to detailed questions concerning firm management);

- disseminating best practices in adoption methodology and improvement measures.

In summary, as the model of RM maturity should define the 'ideal type' of a truly relationship-oriented organization and because the model is intended for empirical testing, the H-D logic seems to be an appropriate methodological framework for this research. However, the soundness of an inductive argument requires that all (relevant) evidence is reflected in the sample (Maher 1996). Therefore, even if the inductive part of the research will rely on the deductive theoretical foundations, there still exist some risks: (1) the theory may turn out to be too vague to gain relevance in field research and (2) the empirical data may potentially turn out to be too ambiguous to provide a clear theoretical interpretation (Ketokivi and Mantere 2010). To mitigate these risks, the following principles for conducting theoretical and empirical research on RM maturity were adopted:

- reflect not only the core characteristics of the RM business model but also all of its reasonable extensions and bordering concepts (risk 1);

- define and illustrate the RM activities and approaches in a feasible, concrete way (risk 1);

- allow differentiation among firms to uncover possible distinctive profiles of the proposed ideal type (risk 2);

- employ a wide grading scale, which enables nuances to be detected between respondents' narrowing perceptions of their RM activities and approaches (risk 2).

The design of the RM maturity conceptualization process displayed in Fig. 3.1 acknowledges the systematic approach to literature review. In contrast to traditional narrative reviews, the systematic approach is a replicable and transparent scientific process helpful in unbiased identification 
of the conceptual content available in the research field, as well as in identifying emerging trends, themes and topics (Gough and Richardson 2018; Vural 2017).

In line with the first adopted research principle, in step 1 of the RM maturity conceptualization the following three groups of tactical, broadly set questions were defined:

- Are there any existing RM maturity models? What is their design? Were they empirically tested against achieving sustainable competitive advantage?

- What are the main streams of research in RM? Are they contradictory, cumulative or supplementary?

- Is there clear guidance over distinctive RM activities and approaches which lead to achieving sustainable competitive advantage?

These questions will be addressed later in this section.

In step 2, the choice of the scientific sources reflecting the contemporary state of high-quality research on RM has to be made, which is not a trivial one because the body of scientific work concerning RM is extensive. Table 3.1 shows Google Scholar results based on different syntaxes of the terms 'relationship management' and 'relationship marketing'. However, obviously they are very popular in scientific English, and therefore these raw Google Scholar results are not a dependable indicator of the real number of relevant scholastic RM contributions.

However, even browsing through the several thousands of papers in databases with more advanced search options, such as ProQuest, EBSCO and the databases of the main publishing houses, is neither feasible nor effective. On the other hand, narrowing the search criteria would contradict principle 1 of the RM maturity conceptualization and would pose the risk of ignoring a potentially valuable stream of RM-related research.

A promising alternative is to concentrate on the most recognizable scientific resources only (Czakon 2011). A good starting point in the search for these resources is the 'List of scientific journals and reviewed materials from international conferences', which is published by the Polish Ministry of Science according to article 267 paragraph 3 of the Act 'Law on Higher Education and Science' of 20 July 2018. The version dated 2 August 2019 contains 29,040 journals and conference publications from all over the world that are recognized as having a notable scientific impact. Their authority is reflected in a points system, starting with 20 points for 


\section{Step 1: Define research guiding questions}

The questions were defined and ordered into four groups, which correspond with the adopted research principle 1

\section{Step 2: Select databases}

44 journals were selected on Table 3 according to the mentioned criteria

\section{Step 3: Choose search criteria}

Broad search criteria adjusted to specificity of used databases were selected and reported in Table 2

\section{Step 4: Apply practical screening}

Inclusion and exclusion criteria were applied to screen all 757 pre-qualified papers by title and 388 by abstract and keywords

\section{Step 5: Conduct the review}

The review has been conducted on 129 selected papers

\section{Step 6: Sythetize results}

13 RM-related themes were identified and the preliminary descriptive analysis was provided

\section{Step 7: Present the results}

Thematic analysis corresponding with the principles 1-2 of the RM theoretical inquiry and contributing to the development of the RM maturity theoretical concept was presented

Fig. 3.1 Design of RM maturity conceptualization. (Source: Adapted from Fink (2010)) 
Table 3.1 Google Scholar search results on RM

Total number of scientific contributions without time restrictions

$\begin{array}{lccc}\text { Search terms } & \text { + 'competitive } \\ \text { advantage' } & \text { + 'business } \\ \text { performance' }\end{array}$

Source: Own enquiry carried out on 18th February 2020; results approximated by search engine

publications with noticeable but still relatively limited impact only and rising within the levels of $40,70,100$ and 140 points to 200 points for highly prestigious periodicals such as Nature and the Strategic Management Journal. The list does not include books; however, their content is likely to repeat and summarize the ideas addressed and discussed earlier by their authors in journal publications.

In order to extract the most qualitative, factual RM-related journals, the following search criteria were applied (the number of journals cumulatively meeting the quoted criteria is given in parentheses):

- journals which are reported to be situated in the realm of management and quality science discipline (3532);

- journals which were granted at least 70 points and which contain one of the following terms in their title: 'management', 'marketing' or 'business' (315);

- journals devoted to strategic management or broadly positioned (e.g. B2B/B2C markets or service markets (44)).

Excluded from the final group were those journals having a specific focus on one industry (e.g. Journal of Hospitality Industry), management/ marketing function (e.g. Journal of Interactive Marketing) or region (e.g. Australasian Journal of Management). It was assumed that specific insights published by these focused journals would diffuse to the mainstream management, marketing and business journals if they reached a certain level of relevance and acceptance. Then, elaborated and confronted with the 
experiences from multiple research areas, they could potentially qualify to build the RM maturity model. In addition, because it is a periodical exclusively devoted to RM, the Journal of Relationship Marketing (rated with 20 points) was included in the final group.

In step 3, the mix of search criteria (given in Table 3.2) was applied across scientific databases which host the content of selected journals. As papers in management are usually extensive publications, which may easily contain numerous terms used occasionally or referring to their peripheral meaning, to direct attention to the key RM research, the query was generally limited to the following search fields: title, abstract and keywords (Czakon et al. 2019). Only where this was not technically possible were wider criteria applied. In addition, the query was limited to papers from 2010 and after because, as time goes by, some concepts may turn out to be fads or passing fashions (Abrahamson 1991) and as such they should not be qualified for contemporary analysis. On the other hand, there are also numerous seminal papers on RM that are dated earlier than 2010. They build the core identity of RM research, including its links to the RBV,

Table 3.2 Search criteria applied to scientific databases

\begin{tabular}{|c|c|c|c|c|c|c|c|}
\hline \multirow[t]{2}{*}{ Publishing house } & \multicolumn{7}{|c|}{ Search criteria } \\
\hline & $\begin{array}{l}\text { Main query } \\
\text { 'relationship } \\
\text { management' } \\
\text { OR 'relationship } \\
\text { marketing' }\end{array}$ & $\frac{\text { ¿ूँ }}{\stackrel{\Xi}{\Xi}}$ & $\underset{\mathbb{N}}{\mathbb{N}}$ & $\frac{\overrightarrow{0}}{0}$ & 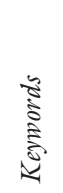 & 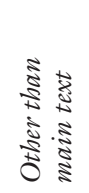 & 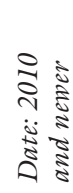 \\
\hline Academy of Management & $\bullet$ & & $\bullet$ & $\bullet$ & & & $\bullet$ \\
\hline Cambridge University & - & $\bullet$ & & & & • & \\
\hline Cracow University of Economics & - & $\bullet$ & & & & & \\
\hline Elsevier & $\bullet$ & & $\bullet$ & $\bullet$ & $\bullet$ & & $\bullet$ \\
\hline Emerald (via ProQuest) & - & & & & & $\bullet$ & $\bullet$ \\
\hline Harvard Business School Publishing & $\bullet$ & $\bullet$ & & & & & $\bullet$ \\
\hline Informs (Management Science) & $\bullet$ & & $\bullet$ & & $\bullet$ & & \\
\hline Informs (via ProQuest) & • & & & & & $\bullet$ & $\bullet$ \\
\hline Sage (Marketing Theory via Ebsco) & $\bullet$ & & $\bullet$ & - & & & - \\
\hline Sage (via Proquest) & $\bullet$ & & & & & $\bullet$ & $\bullet$ \\
\hline Springer & $\bullet$ & & & & & $\bullet$ & \\
\hline Taylor Francis & - & & $\bullet$ & & $\bullet$ & & $\bullet$ \\
\hline Wiley \& Sons & $\bullet$ & $\bullet$ & & & & & $\bullet$ \\
\hline
\end{tabular}


dynamic capabilities and the R-A theory. These were, however, explicitly addressed in Chap. 2. More operationalized concepts that are embedded in this theoretical backbone only emerged after the year 2000 (Gummesson 2017a) and were only developed and tested even later (e.g. the potential and risk of implementing CRM technology; Payne and Frow 2013).

Table 3.3 includes the list of 44 journals qualified for detailed RM maturity conceptualization. Columns 'A', 'B' and 'C' refer to the numbers of papers verified in subsequent review stages. They include step 4 -practical screening by title (A), abstract and keywords (B) - and step 5-full paper

Table 3.3 List of journals and number of referred articles

\begin{tabular}{|c|c|c|c|c|c|}
\hline Journal & Publishing house & Points & $A$ & $B$ & $C$ \\
\hline Academy of Management Annals & Academy of Management & 200 & 0 & 0 & 0 \\
\hline $\begin{array}{l}\text { Academy of Management } \\
\text { Discoveries }\end{array}$ & Academy of Management & 100 & 0 & 0 & 0 \\
\hline Academy of Management Journal & Academy of Management & 200 & 1 & 0 & 0 \\
\hline $\begin{array}{l}\text { Academy of Management } \\
\text { Perspectives }\end{array}$ & Academy of Management & 140 & 0 & 0 & 0 \\
\hline Academy of Management Review & Academy of Management & 200 & 0 & 0 & 0 \\
\hline Business Economics & Springer & 100 & 4 & 0 & 0 \\
\hline Business Horizons & Elsevier & 100 & 16 & 11 & 8 \\
\hline $\begin{array}{l}\text { Entrepreneurial Business and } \\
\text { Economics Review }\end{array}$ & $\begin{array}{l}\text { Cracow University of } \\
\text { Economics }\end{array}$ & 70 & 4 & 1 & 1 \\
\hline Harvard Business Review & $\begin{array}{l}\text { Harvard Business School } \\
\text { Publishing }\end{array}$ & 70 & 0 & 0 & 0 \\
\hline Industrial Marketing Management & Elsevier & 140 & 112 & 91 & 38 \\
\hline International Business Review & Elsevier & 100 & 6 & 5 & 1 \\
\hline $\begin{array}{l}\text { International Journal of } \\
\text { Management }\end{array}$ & Wiley \& Sons & 200 & 23 & 11 & 2 \\
\hline $\begin{array}{l}\text { International Journal of Research in } \\
\text { Marketing }\end{array}$ & Elsevier & 100 & 7 & 1 & 1 \\
\hline International Marketing Review & Emerald & 100 & 0 & 0 & 0 \\
\hline $\begin{array}{l}\text { Journal of Business and Industrial } \\
\text { Marketing }\end{array}$ & Emerald & 70 & 64 & 26 & 5 \\
\hline $\begin{array}{l}\text { Journal of Business Economics } \\
\text { and Management }\end{array}$ & Taylor \& Francis & 70 & 0 & 0 & 0 \\
\hline Journal of Business Research & Elsevier & 140 & 63 & 37 & 20 \\
\hline Journal of Consumer Marketing & Emerald & 70 & 11 & 9 & 1 \\
\hline $\begin{array}{l}\text { Journal of Economics and } \\
\text { Business }\end{array}$ & Elsevier & 70 & 0 & 0 & 0 \\
\hline $\begin{array}{l}\text { Journal of Economics and } \\
\text { Management }\end{array}$ & Wiley \& Sons & 100 & 0 & 0 & 0 \\
\hline
\end{tabular}


Table 3.3 (continued)

\begin{tabular}{|c|c|c|c|c|c|}
\hline Journal & Publishing house & Points & $A$ & $B$ & $C$ \\
\hline $\begin{array}{l}\text { Journal of International } \\
\text { Management }\end{array}$ & Elsevier & 100 & 1 & 0 & 0 \\
\hline Journal of International Marketing & Sage & 140 & 12 & 3 & 2 \\
\hline Journal of Management & Sage & 200 & 0 & 0 & 0 \\
\hline $\begin{array}{l}\text { Journal of Management and } \\
\text { Governance }\end{array}$ & Springer & 70 & 11 & 0 & 0 \\
\hline $\begin{array}{l}\text { Journal of Management and } \\
\text { Organization }\end{array}$ & Cambridge University & 70 & 1 & 0 & 0 \\
\hline Journal of Marketing & Sage & 200 & 18 & 12 & 1 \\
\hline Journal of Marketing Management & Taylor \& Francis & 70 & 3 & 2 & 1 \\
\hline Journal of Marketing Research & Sage & 200 & 9 & 4 & 1 \\
\hline $\begin{array}{l}\text { Journal of Marketing Theory and } \\
\text { Practice }\end{array}$ & Taylor \& Francis & 70 & 0 & 0 & 0 \\
\hline $\begin{array}{l}\text { Journal of Relationship } \\
\text { Management }\end{array}$ & Taylor \& Francis & 20 & 20 & 17 & 2 \\
\hline Journal of Service Management & Emerald & 140 & 23 & 12 & 2 \\
\hline Journal of Services Marketing & Emerald & 100 & 61 & 33 & 13 \\
\hline Journal of Strategic Marketing & Taylor \& Francis & 70 & 11 & 6 & 3 \\
\hline $\begin{array}{l}\text { Journal of the Academy of } \\
\text { Marketing Science }\end{array}$ & Springer & 140 & 157 & 62 & 18 \\
\hline $\begin{array}{l}\text { Management and Organization } \\
\text { Review }\end{array}$ & Cambridge University & 70 & 1 & 0 & 0 \\
\hline Management Research Review & Emerald & 70 & 15 & 6 & 2 \\
\hline Management Science & INFORMS & 200 & 0 & 0 & 0 \\
\hline Marketing Letters & Springer & 100 & 20 & 10 & 3 \\
\hline Marketing Science & INFORMS & 100 & 9 & 6 & 0 \\
\hline Marketing Theory & Sage & 100 & 2 & 2 & 0 \\
\hline $\begin{array}{l}\text { Omega - International Journal of } \\
\text { Management Science }\end{array}$ & Elsevier & 140 & 4 & 2 & 0 \\
\hline Service Business & Springer & 100 & 50 & 15 & 3 \\
\hline Strategic Management Journal & Wiley \& Sons & 200 & 18 & 4 & 1 \\
\hline Strategic Organization & Sage & 100 & 0 & 0 & 0 \\
\hline $\begin{array}{l}\text { Total number of papers } \\
\text { examined: }\end{array}$ & & & 757 & 388 & 129 \\
\hline
\end{tabular}

review (C) (Czakon 2011; Fink 2010). Some of the journals did not publish any paper referring to the search terms in the specified period of time (' 0 ' in column ' $\mathrm{A}$ '). To ensure transparency in the 'A' $/{ }^{\prime} \mathrm{B}$ ' screening process among the remaining journals, several guiding exclusion and inclusion criteria were adopted (Vural 2017). The exclusion criteria were as follows: 
- auxiliary/random use of the searched keywords: keywords were not reflected in the abstract;

- business network structure: papers devoted to an issue that lies beyond the boundaries of the envisioned RM (upper) mid-range theory;

- highly aggregated upper-range constructs: papers exploiting in a general way the impact of familiar relational constructs such as trust and commitment;

- industry- or firm-specific studies: papers with narrowed perspectives without aspirations to provide more general findings (e.g. critical CRM factors in the hospitality industry);

- national- or regional-specific studies: papers which explored the impact of national culture on their findings (e.g. the impact of guanxi on RM) or were presenting results of empirical research based on small samples of firms situated in a peripheral economy (e.g. lessons from Iranian social media businesses);

- management/marketing function-specific studies: papers which exhibited an interest in particular operational tools and techniques without aiming to examine their impact on overall company-wide RM (e.g. micro-solutions such as how to build a successful mobile application).

The inclusion criteria were as follows:

- RM-related models: papers showing how RM-related capabilities affect firm bottom line;

- RM-related activities: papers showing the impact of distinct firm activities and approaches on the quality of its relationships;

- stakeholder value: papers focusing on value created at the intersection of different firm stakeholders from the perspectives of these stakeholders and the firm.

Step 6-preliminary descriptive analysi-revealed 13 main themes which constitute the core of contemporary RM research. As many of them are interconnected, typically each reviewed paper was thoroughly addressing two or three of them, while simultaneously dealing with some others in the background. The statistical values presented in Fig. 3.2 show the topical share of voice based on the main paper narratives.

It comes as no surprise that the most popular theme in the literature is customer relationship management (CRM). These papers were usually 


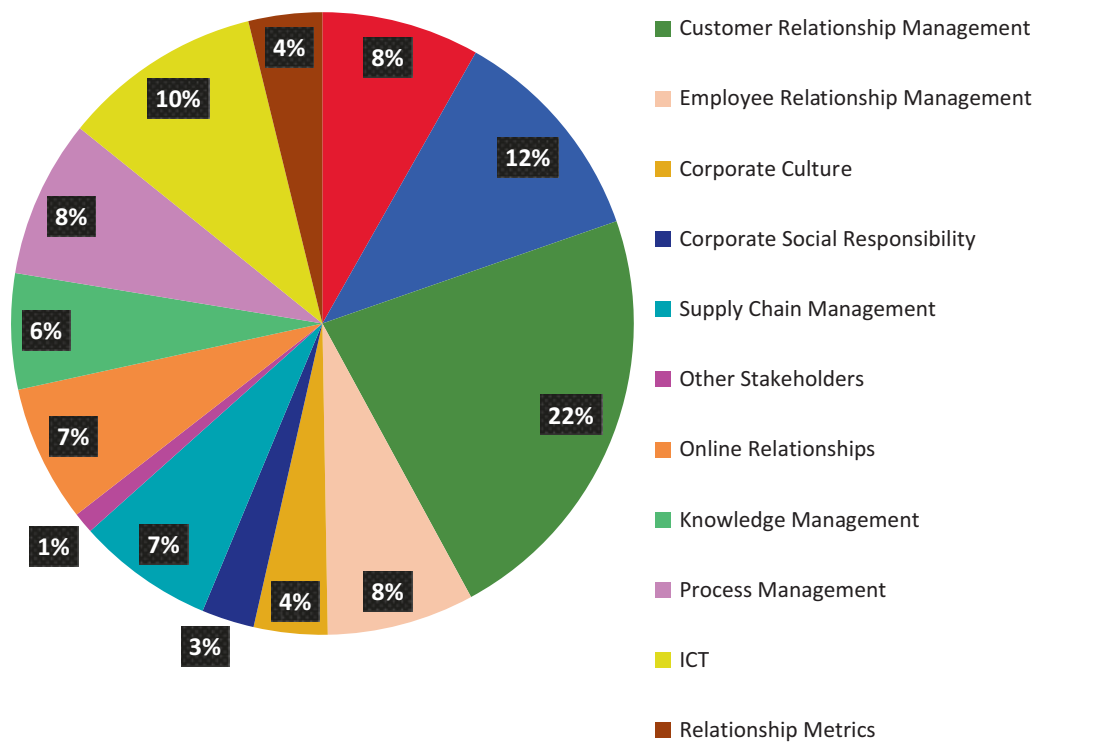

General Relationship Strategy / Orientation

Value (Co-) creation (Service Dominant Logic)

Customer Relationship Management

Employee Relationship Management

Corporate Culture

Corporate Social Responsibility

Supply Chain Management

Other Stakeholders

Online Relationships

Knowledge Management

Process Management

ICT

Relationship Metrics

Fig. 3.2 Descriptive analysis of RM-related content

trying to arrange some processes, tools or techniques and link them with aggregated constructs - for example, distinctive customer-related capabilities. In turn, the impact of these capabilities on broadly understood business performance was examined.

The position of value co-creation as a stand-alone marketing paradigm, and Service-Dominant Logic (SDL) as its underlying theory, is notable in the reviewed literature. Numerous papers related various RM factors to the principles of SDL or to capabilities descending from the notion of customer value co-creation, in a similar manner as earlier in the case of SET-based trust and commitment. Owing to the distinctive characteristics of the service perspective, such as customer-centrism, process orientation, emphasis on dialogue and mutually beneficial cooperation, synergic effects between RM and SDL are frequently highlighted.

Employee management and corporate culture together attracted similar attention to the value co-creation/SDL theme. The corporate culture 
theme was presented as the invisible but decisive factor in securing employee commitment in hard-to-control areas like tacit knowledge management (KM) and empathic customer encounter. At a more operational level, the impact of employee management on successful CRM implementations was examined in the form of, for example, internal marketing and HRM techniques. A supervisor-supervisee relationship was highlighted as the most important single factor affecting employee satisfaction transferable into customer satisfaction, especially in service industries.

The ICT-related literature had a dual focus. Some papers examined the role of ICT-related capabilities in the effectiveness of other business areas, including CRM. Others emphasized the limited impact of ICT investment on company performance if not properly anchored in the organizational context. This included having clear strategic relationship orientation, demonstrated in top management priorities and appropriate project management. The latter took the form of business process optimization and implementation.

Online relationships were another significant topic, related simultaneously to a technological tool and a communication channel. Again the issue of the supportive role of technology was highlighted. However, developing engaged brand communities in social media, frequently given as the main goal of online relationship management, was positioned more as a marketing capability.

Among customers and employees, the third most important group of stakeholders emerging from the examined literature was suppliers. Again, as in the case of CRM and HRM, Supply Chain Management (SCM) was presented as a dynamic capability aggregate and as a natural area for implementing value co-creation strategies. However, a distinctive feature of the SCM-related papers was the significant impact of supplier relationships on innovativeness.

The notion of innovativeness was also visible in the KM-focused papers. However, this was not as breakthrough discoveries but rather as the capability to integrate knowledge-especially customer knowledge-into interactive and analytical processes. As a specific solution to this issue, some papers evaluated the role of various relational metrics in assessing and predicting future customer value. Finally, Corporate Social Responsibility and the relationships with other stakeholders were discussed in a few of the papers.

Following the classic systematic approach to literature review, the descriptive literature analysis usually captures the statistical distribution of 
papers across time, featured industries, applied research methods and geographical regions covered. However, given the goal of this inquiry (defining the preliminary RM maturity model), the appropriateness of such an additional analysis is limited. What does impact the way the detailed thematic review will be conducted is providing the answers to the tactical research questions of this literature review (step 1).

Although varied theoretical or empirically verified models were featured, there were no RM maturity models per se proposed in any of the reviewed papers. The presented frameworks were usually focused on customers or CRM only (by adding the technological dimension to, e.g., a customer-centricity approach) and often continued to apply wide-ranging research constructs such as trust and commitment as organizational ends of RM activities. In consequence they only indirectly examined the impact of the presented models on sustainable competitive advantage by defining additional non-monetary performance constructs, for example relational value. Moreover, most of them operationalized the applied constructs by forming research tools based on general questions prone to ambiguous interpretations and/or focused on a narrow aspect of RM tactics.

Nonetheless, the richness of the identified, predominately specific lowrange approaches based on the dynamic capabilities framework proves the general importance and omnipresence of relationships. This polyphony, although not orchestrated, produced a non-contradictory but supplementary, sometimes cumulative body of research, which is a fairly good starting point for the development of the preliminary RM maturity model. However, two shortfalls make it necessary to adopt the 'snowballing approach' to literature review - that is, to further broaden the thematic literature review (step 7) by locating and exploring some additional scientific sources not appearing in the selected database (Zhang and Banerji 2017). First is the aforementioned scarcity of complex models integrating varied RM-related dimensions/capabilities, which could be potentially published in thus far unidentified sources. Second is the scant evidence on the direct impact of a concrete set of RM activities and approaches on sustainable competitive advantage, which continues to be disguised by various mediating RM constructs on the one hand and by indirect business performance metrics (e.g. customer satisfaction or customer loyalty) on the other.

To facilitate the application of the 'snowballing' procedure in the thematic literature review (step 7), which is offered in the remaining two sections of this chapter, bibliometric software was applied. Figure 3.3 


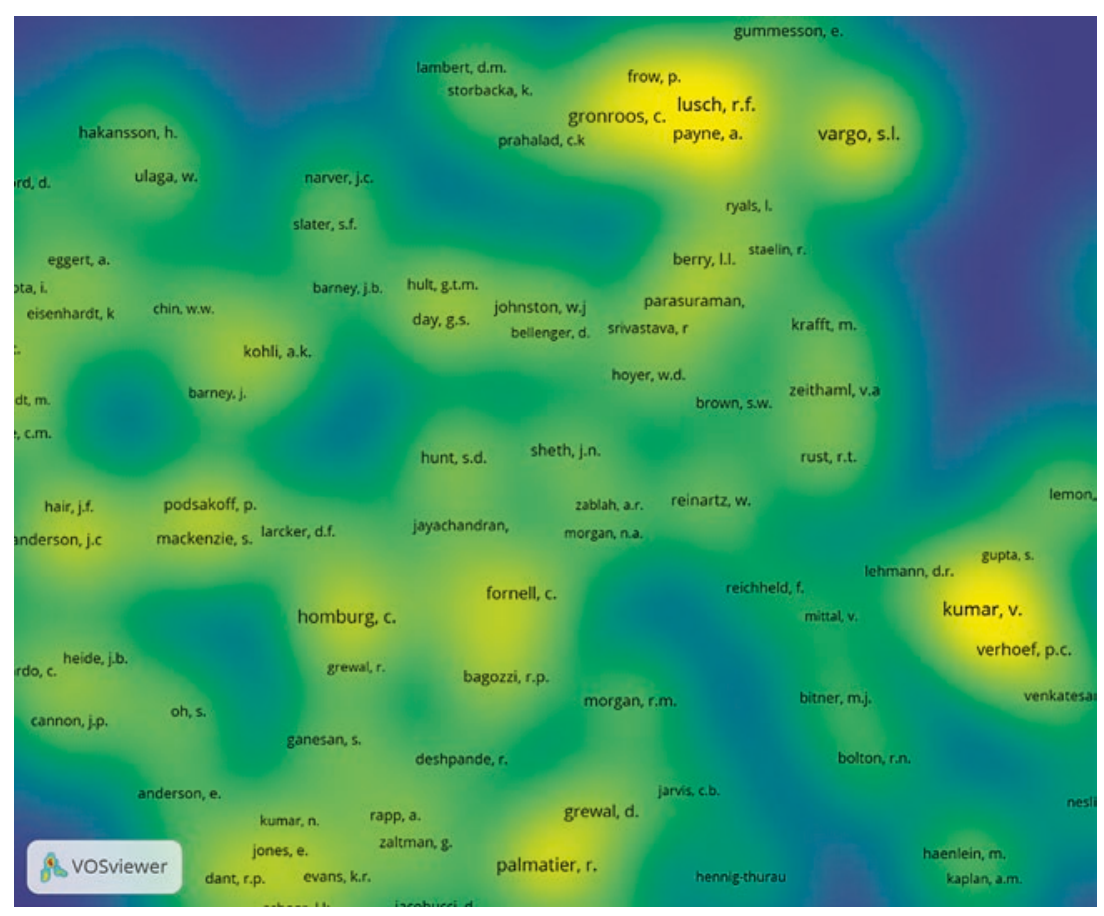

Fig. 3.3 Co-citation density by authors in the reviewed literature. (Source: VOSviewer, version 1.6.14)

shows the co-citation density analysis carried out with VOSviewer, which is a shareware tool for constructing and visualizing bibliometric networks provided by the Centre for Science and Technology Studies at Leiden University, Holland. The relatedness of items shown is based on the number of times they are cited together, thus indicating the importance of the particular author in the scientific field. The relative importance of an author is indicated by the colour (the brighter the better) and by the size of the spot (the bigger the better) behind the name. The minimum number of citations was set at 20 .

Figure 3.4 shows a network visualization of the bibliometric coupling analysis focused on paper citations. The relatedness of items is determined by the number of references they share. Both graphs are interactive (the static figures do not fully illustrate overlapping items) and help researchers to guide their attention in the most promising directions. In this thematic 


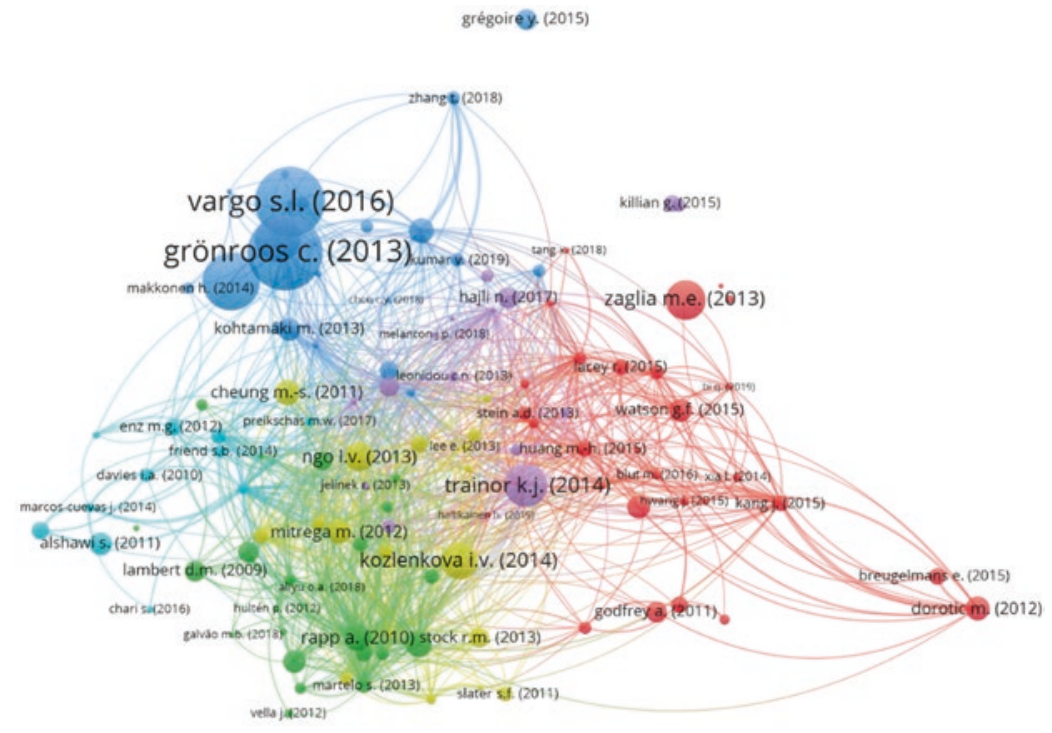

A vosviewer

Fig. 3.4 Most cited papers in the reviewed literature. (Source: VOSviewer, version 1.6.14)

literature review (step 7), the 'snowballing' procedure will be applied within the selected group of academic sources cited in the most influential papers and within the extended body of papers authored by the most influential scholars.

\subsection{The Strategic Dimension of RM Maturity}

The 13 themes identified in the body of RM literature constitute a diversified constellation of theories and empirical material. To reach more clarity and to effectively facilitate the narration of the thematic literature review, they will not be analysed separately. Instead a constructive synthesis is proposed based on the insights from the process-oriented CRM literature, as most, if not all, of these themes can be brought down to a single process or a set of interrelated processes.

In this literature usually three- or four-dimension analytical frameworks are proposed. For example, G. Day insists CRM is predicated on addressing the following areas: strategy, technology, people and processes (2003). 
I. Chen and K. Popovich (2003) describe CRM as an integrated approach to people, processes and technology orchestrated by a "cross-functional, customer-driven, technology-integrated business process management strategy" (2003, p. 673). V. Kumar and W. Reinartz differentiate between four CRM dimensions: organizational alignment, customer management, technology and CRM strategy implementation (2006). D. Lambert, by contrast, highlights the interfaces between the strategic and operational CRM processes and the remaining important corporate processes, such as supplier relationship management, demand management or revenue management $(2008 ; 2010)$. Arguably the most comprehensive model integrating a strategic approach to RM and CRM, found thanks to the 'snowballing' extension of the reviewed literature, is A. Payne and P. Frow's 'CRM strategy framework' (2005; 2013) depicted in Fig. 3.5. In this model the central focus is placed on the strategic dimension that governs the so-called enabling processes (value co-creation, multichannel customer dialogue and IT-powered information management), whose effectiveness is measured within the performance assessment process.

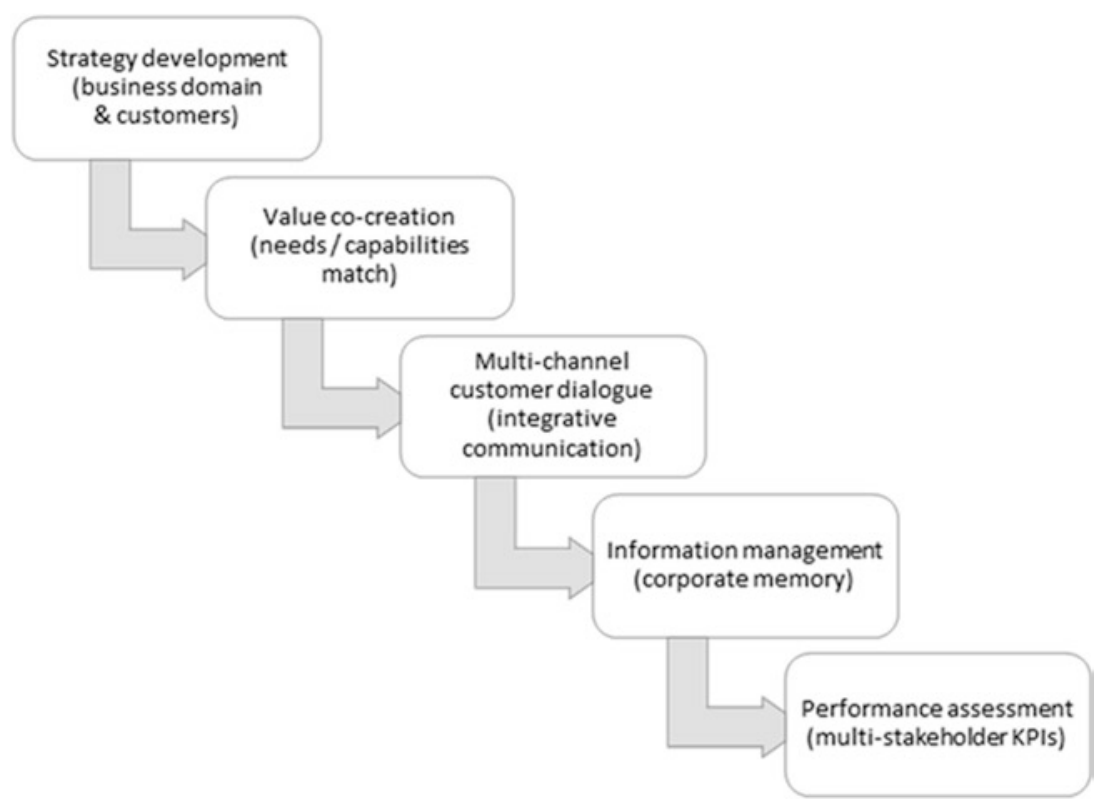

Fig. 3.5 CRM strategy framework. (Source: Adapted from Payne and Frow (2005, p. 171)) 
Given the diversity of proposed analytical frameworks and approaches, the choice of a particular one will always leave some room for controversy. Nonetheless, it seems that a framework that describes the RM maturity should take a slightly more strategic view than the models focused on CRM only, not least because of the necessity to take a whole-company perspective and to facilitate a multi-stakeholder approach. Therefore, the envisioned preliminary RM maturity model will consist of the following dimensions (the indicative placement of the alternative labels found in the evoked conceptualizations is given in parentheses):

- strategic (including people, organizational alignment, strategic processes and value co-creation),

- processual (including customer management, operational processes and multichannel customer dialogue),

- technical (ICT).

As the division between the strategic and processual dimensions is somewhat blurred, some of the themes are simultaneously discussed in these two dimensions, which reflects the dual focus of the literature.

More than one fifth of the analysed papers deal with CRM. However, it is value co-creation and its theoretical foundations (Service-Dominant Logic-SDL) that build the biggest consistent group of RM-related concepts. Therefore, the thematic review of the strategic dimension starts with the SDL and SDL-oriented RM literature, with special focus on the impact of SDL on the overall strategy and the balance between IRM and ERM. In a similar corporate strategy-oriented vein, the issues concerning stakeholder portfolio management will be presented, with emphasis placed on customers and employees as the most important classes of stakeholders. In the case of the latter, the discussion is highly concentrated on the prerequisites of an effective, RM-supportive corporate culture. The processual dimension of the preliminary RM maturity model exemplifies concrete activities and approaches resulting from an RM strategy. The technical dimension includes a general discussion on IT governance, project management and specific instances of ICT systems, with a dominant focus on CRM systems. The dimensions and themes represented in the preliminary RM maturity model are listed in Table 3.4.

The basic foundation of SDL laid out by S. Vargo and R. Lusch in their award-winning article (2004) is that the success of a company is determined by the extent to which it can offer value propositions to its 
Table 3.4 Overview of the thematic literature review

\begin{tabular}{|c|c|c|c|}
\hline Dimension & Theme & Section & Characteristic \\
\hline Strategic & Value co-creation/SDL & 3.2 & $\begin{array}{l}\text { - SDL view on the goals of a firm } \\
\text { - value co-creation in a broad } \\
\text { SDL-sense and in an RM-sense } \\
\text { - interplay between SDL, RM, RBV } \\
\text { and dynamic capabilities }\end{array}$ \\
\hline Strategic & $\mathrm{KM}^{*}$ & 3.2 & - importance of relational learning \\
\hline Strategic & $\begin{array}{l}\text { General relationship } \\
\text { strategy / orientation }\end{array}$ & 3.2 & $\begin{array}{l}\text { - complexities in simultaneously } \\
\text { addressing different stakeholder } \\
\text { interests } \\
\text { - alignment of business strategy and } \\
\text { ethics }\end{array}$ \\
\hline Strategic & CSR & 3.2 & $\begin{array}{l}\text { - external/internal focus of CSR } \\
\text { initiatives }\end{array}$ \\
\hline Strategic & $\begin{array}{l}\mathrm{CRM}^{*}, \text { SCM \& other } \\
\text { stakeholders }\end{array}$ & 3.2 & $\begin{array}{l}\text { - customer portfolio management and } \\
\text { relationship economics } \\
\text { - reciprocity to preferential treatment } \\
\text { - customer quality definition }\end{array}$ \\
\hline Strategic & $\begin{array}{l}\text { Corporate culture \& } \\
\text { employee management* }\end{array}$ & 3.2 & $\begin{array}{l}\text { - cognitive culture types } \\
\text { - emotional culture types } \\
\text { - culture values matching relational } \\
\text { approach } \\
\text { - employee management policies } \\
\text { resulting from RM-supportive } \\
\text { culture }\end{array}$ \\
\hline Processual & Employee management* & 3.3 & $\begin{array}{l}\text { - employee motivation } \\
\text { - supervisor-supervisee interactions } \\
\text { - employee empowerment } \\
\text { - internal market orientation }\end{array}$ \\
\hline Processual & $\mathrm{CRM}^{*}$ & 3.3 & $\begin{array}{l}\text { - relational communication \& } \\
\text { relational selling }\end{array}$ \\
\hline Processual & $\begin{array}{l}\text { Process management \& } \\
\mathrm{KM}^{*}\end{array}$ & 3.3 & $\begin{array}{l}\text { - lead management } \\
\text { - loyalty management } \\
\text { - process enrichment by customer } \\
\text { knowledge } \\
\text { - complaint management }\end{array}$ \\
\hline Processual & Relationship metrics & 3.3 & $\begin{array}{l}\text { - RFM, CLV, NPS } \\
\text { - importance of measuring the health } \\
\text { of relationships }\end{array}$ \\
\hline Processual & Online relationships & 3.3 & $\begin{array}{l}\text { - principles of relational social media } \\
\text { dialogue }\end{array}$ \\
\hline ICT & ICT & 3.3 & $\begin{array}{l}\text { - potential benefits } \\
\text { - areas of application (CRM, HRM, } \\
\text { KM) } \\
\text { - project management }\end{array}$ \\
\hline
\end{tabular}

Themes and their characteristics given in order of appearance. '*'-marked themes are related both to strategy and processual instances 
customers. Moreover, it is not the company that creates value but the customers (beneficiaries) themselves. The company may get an opportunity to engage in the customer's value creation process as a co-creator, and to collaborate in resource integration that both parties bring as they interact, but always it is only the customer who is the value creator (Vargo and Lusch 2008). The main SDL idea is brilliant and simple: companies should focus on the customer, not on themselves, because the more individual the result of the co-creation process, the more favourable the assessment of value by the customers and their intentions to spend more with the firm (Ngo and O'Cass 2013). Even hardline manufacturers can leave the area of tangible product delivery and concentrate on the process of value cocreation, as service is the basis of any exchange in all industries. It is also a proven way to become meaningful to customers and differentiate the value proposition (Grönroos 2016; Vargo and Lusch 2004).

However, here is the problem. The co-creation process occurs by definition when a company processes the body, mind or possessions of the customer cooperatively (Wirtz and Lovelock 2016). It can take the form of value co-ideation, co-design, co-production, co-test or co-launch (Ramani and Kumar 2008; Russo-Spena and Mele 2012). But what if, for example, an individual fast-moving consumer goods (FMCG) customer or a business customer ordering stationery is not willing to actively collaborate because the area where the company offers its competences is beyond their core interest, or the perceived additional value this process could produce does not correspond to the costs (e.g. time devotion)? After the definition of S. Vargo and R. Lusch, the 'service economy' is embodied in the processes of using resources of partners for their benefit $(2008$, p. 7$)$. Therefore, value co-creation is "simply a positive statement that, at least in human systems, which are characterized by specialization and thus interdependency, value is always co-created" (2016, pp. 8-9). In other words, if broadly defined, value can be co-created even without an active company-customer interaction, because the resources embedded in the offer can be autonomously integrated by the customer.

RM does not go that far. Although, given the available technology, customers do not necessarily need human-to-human contacts to interact with the company (e.g. they can use self-service at the website), the company should still analyse automated contacts and (if necessary) instantly react by proactively sparking dialogue. In consequence, no relationalbased value co-creation can take place unless interactions between the company and the customer or other stakeholders occur (Gummesson 2017a). By contrast, when an individual customer applies moisturizing 


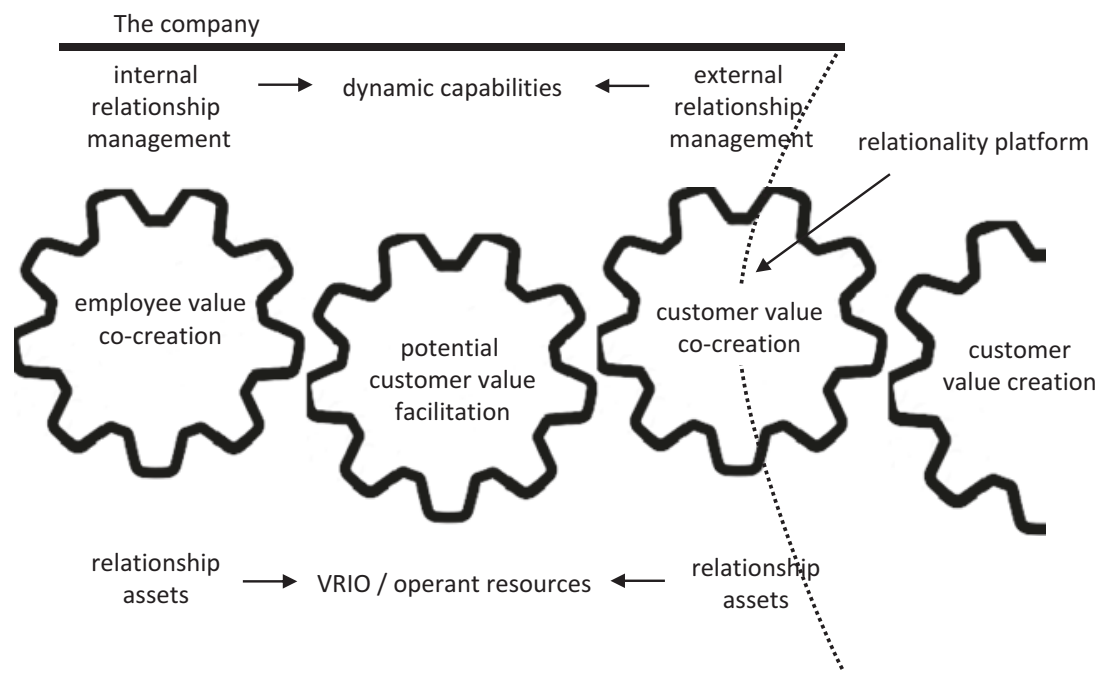

Fig. 3.6 The interplay between RM and SDL

cream to their face or the employees of a business client use a flipchart in a meeting, they do integrate these resources and they do generate some services upon them (value co-creation in a broadly defined SDL sense), but in a way that leaves the company involved in a dormant position (no value co-creation in an RM sense).

In general, however, the relational and value co-creation paradigms overlap (Preikschas et al. 2017). For instance, key concepts in SDL (value co-creation, collaboration, resource integration, interactivity and value creation networks) are relational (FitzPatrick et al. 2015). Service is also relational, and at the same time relationships are based on service (Grönroos 2017). Therefore, RM and SDL are believed to have the potential to be integrated into a single and relatively coherent conceptual structure (Gummesson and Mele 2010). Although it is not the intention of this book to provide such a framework, in Fig. 3.6 a brief overview of the interplay between RM and SDL embedded in the resource-based and dynamic capabilities theories is proposed. The RBV acts here as a general theory for value creation from the perspective of a company, stating that VRIO resources will give a company a sustainable competitive advantage in a particular area. In SDL, VRIO resources are labelled 'operant resources' and draw on the notion that intangibles, especially knowledge, are the fundamental source of 'strategic benefit' (as Vargo and Lusch now call 
competitive advantage; 2016). This can be monetized thanks to dynamic capabilities, which are essentially relational capabilities (e.g. network competence, alliance competence, internal market orientation, customer response capability, interaction orientation and relationship management capability; Jayachandran et al. 2004; Madhavaram et al. 2014).

To make this happen, all corporate functions must learn to collaborate with each other and across the customer and supplier organizations (Enz and Lambert 2012). In this context, the key managerial concern should be the development of a "relationality platform" (Grönroos 2016) or a "co-creation framework" (Sheth 2017). The RM-mature company should therefore coordinate multiple human and machine-assisted physical, mental or virtual communication channels to offer meaningful interactions that provide emotional engagement and positive surprise and-which is so essential to the co-creation process-integrate customer knowledge (Kaski et al. 2018; Payne et al. 2009). The latter comes in the form of relational learning (information sharing, joint sense-making and knowledge integration) and is an inalienable part of any customer-facing process (Cheung et al. 2011; Martelo et al. 2013).

Such a persistent dynamism also requires continuous coordination of internal and external relationship management processes (IRM and ERM). IRM is directed at co-creating value with employees, thereby enhancing VRIO/operant resources. ERM is directed at co-creating value with customers (external beneficiaries) and ultimately reflects the dynamic capabilities of a company.

The interplay between IRM and ERM is as follows. To create an attractive value proposition for external customers, the value facilitation process that takes place inside the company has to be built around and within the VRIO/operant resources. These resources can be used in the value facilitation process, but do not have to be. They are dormant in the employees, unless they become activated by proper HRM techniques (acknowledging individual skills, preferences and ambitions of employees) and an overall partnership between the workforce and the management team (effective corporate culture). The activation of VRIO/operant resources requires that the employees become internal customers of management and that they are invited to participate in an internal value facilitation process as co-creators and important co-beneficiaries (Grace and Lo Iacono 2015). Only by perceiving their work as a relationship in which they have a stake will employees directly and indirectly support relational selling strategies and techniques and believe they will enjoy greater personal benefits the more they try (Arli et al. 2018). By contrast, a purely transactional 
approach to work (time vs. pay) incentivizes employees to mediocrity, because the less effort they put into their work, the better outcome they get out of this exchange (Grandey 2003). Therefore, the odds for successful ERM are linked to successful IRM (Chomiak-Orsa 2016), because employees are the ones who, by creatively participating in the utility value facilitation process and by empathetically helping customers in the application of the resources their company provides, make such a relationship truly beneficial (Delpechitre et al. 2018). Hence, one can reframe RM maturity and value co-creation and converge them into a unified process and system for enhancing customer value, firm relational assets, competitive advantage and societal well-being (Lusch et al. 2010).

To sum up, in the light of SDL, a practical implementation of the RM business model is based on making interactions more meaningful to customers and other stakeholders. Therefore, the goal of an RM-mature firm is to merge as much as possible of what were previously solely internal corporate processes (proactively inviting customers to take a role in a corporate process) and individual customer processes (being open to an invitation to take a role in a customer process). This can be achieved by constantly improving the processes and providing resources that help customers to create value in their individual processes (value-in-use; Macdonald et al. 2011). Examples include designing a new product or service, customizing the functional requirements of existing products, changing procedures in logistics or in communication, and also simply making sure customers feel asked/welcomed to co-participate in something that has relevance (Minkiewicz et al. 2016; Svendsen 2011). In consequence, the odds for a successful co-creation are higher the more touch points the company offers its customers and other stakeholders that enable more vivid interaction at different stages of value creation (Grönroos 201 la).

Nonetheless, an increased corporate commitment to co-creation has its limits. The customers have to be able to spend more on individually tailored offers, and the trade-off between the additional co-created value and generated costs should provide a strong argument to support such a decision. This means that the business model of an RM-mature firm that supports value co-creation processes has to be realistic and selective, because not every relationship is able to generate enough value for both sides (Deszczyński 2016a).

The competitive advantage of a company is influenced by the quality of its relationships with its employees and customers, as well as with an array of other stakeholders, including owners/shareholders, competitors, suppliers, distributors and influential institutions (Fonfara 2014). In his 
concept of 'total relationship marketing', E. Gummesson identifies 30 forms of RM, including the management of nano-relationships (e.g. between marketing and operations management), special relationships (e.g. green relationships and CSR, e-relationships, relationship to a customer's customer, relationship to a dissatisfied customer) and mega-relationships (e.g. personal and social networks; 2017b). The concept of 'total relationship marketing' pinpoints a narrow myopic vantage point of traditional transactional marketing, which extracts the company from its natural environment and struggles to concentrate on the direct short-term market variables only (Gummesson 2012). A mature RM company should, by contrast, clearly reinforce its existential basis, or its RM programme will never develop beyond a technicality (Gummesson 1999). Therefore, in general, RM maturity should be demonstrated in the way business leaders address the moral complexities of RM resulting from diverse stakeholder claims (Lindgreen and Swaen 2010; Jakubów 2016) and balance investments to avoid value asymmetry, which would cause such relationships to deteriorate (Luu et al. 2018; Morgan and Hunt 1994). This is clearly a strategic endeavour, which should be reflected both in declarations of intent and in ongoing business practice.

In their 'CRM strategy framework' A. Payne and P. Frow $(2005 ; 2013)$ thoroughly discuss the key processes, which they merge into a coherent practice-oriented inductive CRM model. They pay much attention to the strategic importance of RM by incorporating its core characteristics and objectives into the global strategy development process. Such an alignment involves inspiring the mission and vision with the relationship spirit, which goes far beyond making money and cannot be disposed to short-changing (Collins and Porras 2002). In addition, some authors emphasize the necessity to strategically promote business ethics and to position the company in a broader network of relationships including its social partners (Eveland et al. 2018; Hwang and Kandampully 2015; Sheth 2017). This would differentiate an RM-mature company from its transactional competitors, who tend to take the view that business ethics and market competition are contradictory forces (Baumol and Blackman 1991; Teneta-Skwiercz 2008).

All corporate social initiatives beyond legal obligations are generally labelled Corporate Social Responsibility (CSR; Schuler and Cording 2006; Wąsowska and Pawłowski 2011). Nonetheless, a company itself is a social construct, and employees are its strategic public (Grunig 2008). Hence, philanthropy - traditionally linked to CSR - is highly desired and prized (Carroll 1991), but before venturing out to solve larger societal problems, companies should first set their own house in order through practising 
purpose-driven internal relationship management (Sasidharan Dhanesh 2012). This could act as an instance verifying whether CSR is strategically important or is only a marketing trick (L'Etang 1994). Concerning external relationship management, even without a CSR label a company can act responsibly and attract customers by educating them, discouraging mindless consumption and attaching spiritual value to its brands, which may eventually achieve the status of moral compasses (Peppers and Rogers 2013; Sheth 2017). Such perceptions create relational value and a cognitive and affective basis for customer reciprocal gratitude (Hwang and Kandampully 2015; Lacey et al. 2015). Its behavioural manifestation is consumer preference towards the company, which translates relationship investment into tangible returns on relationship (ROR; de Ruyter et al. 2019).

Among other things, defining key groups of customers (including distribution channel partners) remains a strategically important task (Payne and Frow 2016). A crucial decision to take here is the level of detail of customer insight a company possesses and can effectively utilize, which is reflected in customer segment granularity (Payne and Frow 2005; 2013). The best way to maximize the lifetime value of desirable customer segments, A. Payne and P. Frow propose, is the shift from making, selling and servicing to listening, customizing and co-creating (2013). Therefore, one of the priorities of the top management of a mature RM company should be to specialize in preserving and enhancing its knowledge of the ways its relevant partners create value, and to show a healthy level of flexibility (e.g. customization and individualization) by providing value propositions/ resources that fit into its practice constellations (Storbacka et al. 2012).

The selective approach to managing relationships with different customer groups is in line with the Key Account Management/Global Account Management literature (Chari et al. 2016; Guesalaga and Johnston 2010; Marcos-Cuevas et al. 2014; Shi and Gao 2016), Customer Portfolio Management literature (Johnson and Selnes 2004; Thakur and Workman 2016) and SCM literature (Forkmann et al. 2016; Oghazi et al. 2016). The underlying logic of such an approach is again the concept of partner gratitude. Its strategic manifestation is the adoption of preferential treatment policies and tools, which is believed to be one of the most effective ways of strengthening relationships (Huang 2015). Preferential treatment may be translated to a general priority in accessing and integrating firm resources (e.g. reducing waiting time for service) and in demonstrating some extra effort to ensure highly personalized experiences are 
consistently offered at all times (Ashley et al. 2011; Kumar et al. 2019). However, for an RM-mature firm, granting preferential treatment cannot remain an isolated act. On the contrary, it has to be mirrored by an active participation of engaged customers which, besides resource integration, involves partner knowledge sharing and partner learning, and conditions value co-creation and partner operant resource development (Hollebeek et al. 2019; Ngo and O'Cass 2013). In this context, engaged partners are also an important source of innovative ideas (Dyer and Singh 1998; Prior 2012) and a firm-initiated resource of their own (Alvarez-Milán et al. 2018). Nonetheless, receiving preferential treatment may not always bring positive attitudinal and behavioural consequences, if not based on transparent rules and if the overall quality offered for the wider customer base is not adequate (Xia and Kukar-Kinney 2014).

An open system of value co-creation and multi-layered relational embeddedness challenges all organizations in terms of adaptability and flexibility (Grönroos 2011b). Much of this challenge is about shifting the managerial focus from the firm's to the customers' resources and processes and developing a thorough insight into customers' definitions of quality (Grönroos 2017). As a consequence, a mature RM firm should continuously evaluate all of its processes to the extent that they contribute to customer value creation, much of this in collaboration with its key suppliers (Miocevic and Crnjak-Karanovic 2012). Simultaneously it should control for migrations in its stakeholder portfolio to adjust policies and investment in its human and organizational infrastructure (Keramati et al. 2010). As a consequence, priority must be given to the alignment of synchronized and (if necessary) reengineered processes and varied incentives, encouraging employees to show a proactive attitude towards customer interactions and engagement in delivering the co-creational customer experience (Pozza et al. 2018).

An overarching construct that spans all internal RM activities is corporate culture, which comprises four interrelated components: shared values, norms, artefacts and behaviours (Hogan and Coote 2014; Schein 1990). Exemplary cultural capabilities that have been captured empirically and proven to be effective (at least in terms of creating employee satisfaction) are, for example, collaboration, communication, flexibility and interaction (Conrad et al. 1997; Eisenhardt and Martin 2000; Sriramesh et al. 1996). By contrast, according to customer value-based theory of culture, companies that organize themselves to support customer value delivery processes achieve superior business performance (Slater 1997). However, corporate 
culture is a source of competitive advantage only when it is deeply internalized and socialized and when it enables the effective execution of the chosen business strategy (Barney 1986; Kim Jean Lee and Yu 2004). In their established model of competing values, R. Quinn and J. Rohrbaugh conceptualized four cognitive culture types characterized by their dominating focus (internal vs. external), organizational structure (flexibility vs. stability), and organizational means and ends (1983). Out of these four, the so-called Human Relations Model, which is widely known as the 'Clan' culture type, is probably the best match for the RM strategy (Slater et al. 2011). Its underlying values-flexibility and internal focus on the well-being and development of employees - create a sense of family belonging and foster good teamwork and employee empowerment (Cameron and Quinn 2011; Denison and Mishra 1995). This is of the highest importance in any internal arrangement where the 'essence' of the firm displaces market-like incentives (Teece et al. 1997). This is exactly the case if decision making is uncertain, long-range planning is difficult and, as seems to be a hallmark of RM and SDL, the degree of work complexity and required outside-the-box thinking makes it infeasible to scrupulously instruct employees and assess their performance (Cameron and Quinn 2011; Yu and Wu 2009).

A complementary approach to cognitive corporate culture research is emotional culture studies. Emotional culture is defined as "shared affective values, norms, artifacts and assumptions that govern which emotions people have and express at work and which ones they are better off suppressing" (Barsade and O'Neill 2016, p. 4). There exists some empirical evidence that by awakening such emotional states as joy, happiness, excitement, and companionate love and warmth, an organization contributes to its employees' psychological need for autonomy, mutual respect, care, competence and relatedness (Ryan and Deci 2017). According to human self-determination theory, this produces trust, satisfaction, mutual control and employee commitment towards such an organization (Barsade and O’Neill 2016; Men and Robinson 2018; Scherer 1997). By contrast, employees in dispirited organizations with a demoting emotional culture of sadness or a tense and anxious culture of fear are less likely to satisfy their psychological needs at work (Creed 2003; Diefendorf et al. 2008; Scherer 1997). In consequence it is expected that most of them will not develop a quality relationship with either the company or its external partners (Barsade and O’Neill 2016). 
Corporate culture is, by definition, not a stable phenomenon. Therefore, all cultures incorporate some of the modelled features in different proportions over time. In general, however, an RM-supportive culture ought to serve a purposeful strategy and should be passionate about achieving meaningful objectives (J. Collins and J. Porras, based on their longitudinal observation of corporate high achievers, coined the expression 'Big Hairy Audacious Goals'; 2002). Further on, it should manifest itself in a strong internalization of a long-term customer orientation aligned with less formalized, flexible organizational structure easily facilitating customer knowledge sharing, employee empowerment and behaviour-based evaluation, and work-group socialization (Ling-Yee 2011; Hartline et al. 2000). Finally, it ought to remain adaptable and entrepreneurial (Bratnicki and Brzeziński 2019; Kotter and Heskett 2011). This means it should leave room for experiments allowing the sensing, testing and capture of unanticipated fleeting macro- and micro-market opportunities (Sull and Eisenhardt 2015), so that the organization remains change-friendly and resilient (Kotter and Heskett 2011; Prahalad and Hamel 1994). Figure 3.7 presents a brief summary of the components of the strategic dimension of the RM maturity model integrated with the SDL.
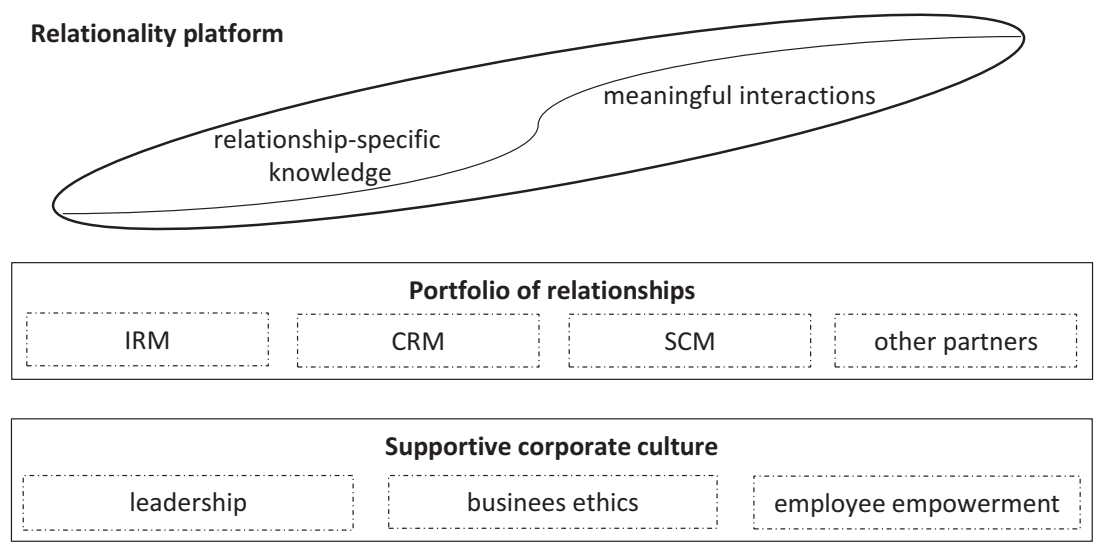

SDL and RM-inspired mission,vision and strategic goals

Fig. 3.7 Strategic dimension in preliminary RM maturity model 


\subsection{The Processual and ICT Dimensions OF RM MATURITY}

The business processes dimension of the RM maturity model mirrors and expands the themes introduced in the previous section. Especially regarding customer-facing processes, the RM literature comes with a variety of ideas and concepts (Cheng and Yang 2013). However, this section starts with employee-focused processes because the alignment between theses two is crucial for successfully implementing the RM business model (Aliyu and Nyadzayo 2018; Pozza et al. 2018).

Sharing the same domain as corporate culture, HRM is a critical process that enhances the individual and collective capabilities of employees (Orr et al. 2011). Process theories of motivation emphasize that apart from extrinsic motivation (e.g. remuneration), there exists also intrinsic motivation derived from the nature of the organization, its management and its culture (do Nascimento et al. 2018). Hence, HRM is affected by corporate culture and at the same time creates this culture as well. As the core element of IRM, HRM directly affects the quality of companyemployee relationships (Ryan and Deci 2000), which is an aggregate composed of individual relationships within an organization. Among them, the relationship with the direct supervisor seems to be the most important. Therefore, RM implies lifting the command-and-control management style and requires balancing powers (Herington et al. 2009) as interdependence is crucial to the longevity of any social exchange relationship (Blau 1986; Lambe et al. 2001). The shift from a traditional 'master and slave' management to a 'partnership in a relationship' creates demand for true leaders at all management layers. Their domain is not detailed work distribution and control, but fostering collaboration, strategic planning, leadership and innovation (Hawkins and Little 2011). To better address the needs of their teams, 'transformational leaders' (as they are sometimes called) share power and communicate in an interactive, caring, visionary, passionate and empowering way (Men 2014).

Employee empowerment is an important HRM capability which to a large extent conditions customer value co-creation (Zhang et al. 2018). As these interactions are dialogical, only employees who can act as equal partners of customers and other stakeholders add to a positive encounter (Grönroos 2011b). A typical situation when this is not the case would be a conversation with a customer contact centre employee who behaves as if they had swallowed the service manual and is not allowed to take any 
decisions. Therefore, it is somewhat impractical to propose a detailed catalogue of isolated high-performing work practices. Autonomy or mutual respect will be differently demonstrated on the manufacturing line, in telemarketing teams, among stock exchange traders, in a police squad, in a philharmonic orchestra or in a monastery. However, there must exist a complementarity among different HRM activities which is effective in a given organizational context (Ichniowski et al. 1997; Colombo et al. 2007).

What can be expected to be important regardless of the organization's specificity is to ensure all team members have a positive perception of their work and their place in the team. In turn, this makes them develop socalled positive psychological contracts with the company, which generally translates to showing reciprocity adequate to formal and informal stimuli received from the company and its representatives (Mangold and Miles 2007). An RM-mature firm will therefore make sure that its HRM policies and activities contribute to a genuine orientation to the internal market (Gounaris 2006). This means that before developing the relationality platform for the external stakeholders, the company has to create conditions for developing an internal one (Grönroos 2016). Such a company makes their employees feel treated fairly, by providing them with satisfactory and time-accurate information on the workflow they are engaged in, by applying transparent work assessment and remuneration criteria, by communicating openly and encouraging open dialogue in the teams, and by being open to innovative ideas (Giannakis et al. 2015; Giannakis et al. 2015; Madhavaram et al. 2014).

The variety of customer-facing processes is wide. However, they all come under the umbrella of the relationship communication process (Payne and Frow 2005), which aims to maximize the value of the relationship during its whole lifetime (initiation, maintenance and termination; Reinartz et al. 2004). As a logical consequence of the RM business model, relational communication is not entirely focused on selling but rather on customer consulting, and is not concentrated on transmitting information but rather on evoking a meaningful dialogue (Balaji et al. 2016; Wagner and Benoit 2015). The reason for this and simultaneously the cornerstone of any successful RM business case is that an RM-mature company should not strive to merely satisfy the customers, but to delight them. Given the range of alternative choices, only completely satisfied customers have a strong reason to stay loyal, as only then is the chance of finding an equivalent offering scarce and the risk of losing a good supplier/vendor high (Jones and Sasser 1995). Setting apart the other factors (e.g. total product 
satisfaction), delight is mainly driven by interpersonal adaptive behaviour of customer service personnel and directly precedes reciprocal gratitude (Bock et al. 2016). The way to convert relational strategy into relational communication to end up with successful relational selling is not primarily a matter of applying any particular technique (Arli et al. 2018), but is rather an IRM-sponsored product of the internalization of customer orientation (Guenzi et al. 2007), which has been described earlier in this and the previous section. Nonetheless, the literature comes with some tactical ERM processes, which ought to define an RM-mature firm.

In their 'CRM strategy framework' A. Payne and P. Frow organize the general customer communication process by communication channels, which greatly resembles the departmental division of responsibilities (2013). Alternatively, one can study distinct communication processes as they go through departments. The group of such generic interdepartmental processes includes lead management, loyalty management and complaint management (Virtanen et al. 2015; Dorotic et al. 2012; Álvarez et al. 2010).

Lead management is an acquisition process aimed at the systematic registration and timely procession of information about customer interest in company offer (Baran and Galka 2017). The essence of lead management is to provide prospective buyers (both existing and new customers) useful information and solutions in the right place and at the right time. It can take the form of the prompt response to submitted requests or a proactive proposal based on processed customer knowledge.

Companies invest substantial sums in marketing actions generating leads, but most of these are ignored by salespeople (Deszczyński 2016b; Ohiomah et al. 2019). Poor lead follow-up could be the result of competing demands on salespeople's time (Sabnis et al. 2013), but the real cause may be unsatisfactory IRM. Only smooth internal collaboration (e.g. among customer contact units, sales and marketing) enables relational selling and yields a significant improvement in the quality of the lead management process (Smith et al. 2006). In turn, a RM-mature firm should be characterized by a no-waste lead policy.

Loyalty management is commonly associated with loyalty programmes and discounts. However, firms should carefully analyse the potential costs and benefits of such programmes and apply them selectively (Dorotic et al. 2012). Moreover, as loyalty is not a simple mechanism of repeating purchases but a complex behavioural phenomenon, a proper loyalty programme should reach far beyond the surface of frequent purchase 
promotions and utilize customer knowledge to generate highly appealing proposals. The formula for sustainability of relationships includes customer needs definition, preferential treatment policies preceded by intelligent analytics, integrative communication plans and focus on value co-creation (Galvão et al. 2018; Ma et al. 2018). For an RM-mature firm, loyalty management is also a vital part of its acquisition strategy. Stable relationships produce referrals, which may be a source of sustainable growth (Terho and Jalkala 2017; Van Den Bulte et al. 2018). Such an organic expansion does not proceed at the expense of customer service quality, as the company has time to adjust its infrastructure to increased demand.

A good application of complaint management requires admitting if the company failed to deliver the expected quality and analysing why it happened, learning what the customers expect, providing compensation guidelines and allowing frontline personnel to award an individual redress (if needed; Homburg et al. 2010). The goal is to make customers perceive justice by promptly providing decent solutions to reported problems (Cambra-Fierro et al. 2016). Obviously these problems fall into some foreseeable categories; however, as the individual circumstances may differ, it is not possible to fully automate the process. Thus again, trained, motivated and engaged employees are an indispensable element of positive customer encounters, which in the case of complaint management are not only about settling a problem but also paving the way for relationship recovery and its future development (Álvarez et al. 2010). In this context, for an RM-mature company complaint management is an element that conditions future repurchases and should be treated not as a cost but as a relational investment.

All customer communication processes have to be parameterized to enable their proper management, but also to reflect the discrete relationship economics in more aggregated measures such as RFM (recency - frequency - monetary value), CLV (customer lifetime value) and NPS (Net Promoter Score; de Ruyter et al. 2019; Neslin et al. 2013; Reichheld 2006; Singh and Singh 2016). As a logical consequence of RM business model adoption, these metrics should be followed in a given analytical cross-section by top management with the same attention as financial indicators. In fact, firms that analyse links between non-financial measures and value creation find themselves in a better position to improve the bottom line than those focused on financial indicators only (Mauboussin 2012). Especially an RM-mature company should be aware of the causal links 
between the variation and trends in length, depth (frequency of contacts including transactions) and breadth (customer wallet share) of relationships across different segments in its portfolio and financial performance (Holm et al. 2012). Measuring the health of relationships also includes following the developments in the employee portfolio (Reichheld 2001).

In addition to the traditional direct ERM processes, Social-CRM (communicating via social media) emerges in many publications as an important CRM process (Hajli et al. 2017; Sheth 2017). However, merely creating a social media presence cannot be viewed as an instance of RM maturity (Heavey et al. 2020). Truly relational Social-CRM activities refer to the way a company interacts with its customers, who are no longer passive information receivers but take the role of active broadcasters whose voices co-create the ultimate online brand-community encounter and influence company operations (Melancon and Dalakas 2018; Zhang et al. 2017). Only these marketer-generated communities, which are primarily centred on meaningful interpersonal interactions, produce social ties that make them resemble consumer-generated offline and online embedded brand communities (Bi 2019; Zaglia 2013). Therefore, going social necessitates tremendous involvement and consistency in following the dialogical principle of 'listening and responding' in order to engage customers in value creating dialogue (Deszczyński 2017; Killian and McManus 2015). Thus, the sustainability of any online brand community depends greatly on the website 'stickiness', which is the ability to stimulate commitment and continued participation in community life (Roy et al. 2014; Wirtz et al. 2013). Social media capability, especially in the B2B sector, also includes proficiency in generating and integrating customer knowledge in the multichannel dialogue process (Trainor et al. 2014). A social online dialogue certainly also has a technological context. The ICT themes will be covered in the coming paragraphs in detail. However, a summary of the themes addressed in the processual dimension of the RM maturity model is presented in Fig. 3.8.

The role of ICT in improving the effectiveness of management had been noted long before CRM systems were introduced (Schwalbe 2008). For example, IT systems are one of the factors influencing business strategy implementation in the McKinsey 7S model (Waterman et al. 1980). Furthermore, collaborative RM processes in medium and large organizations have to be powered by ICT solutions (Payne and Frow 2013). The number of customers, employees, physical and virtual locations, and distribution of interactions over time would otherwise make it virtually 


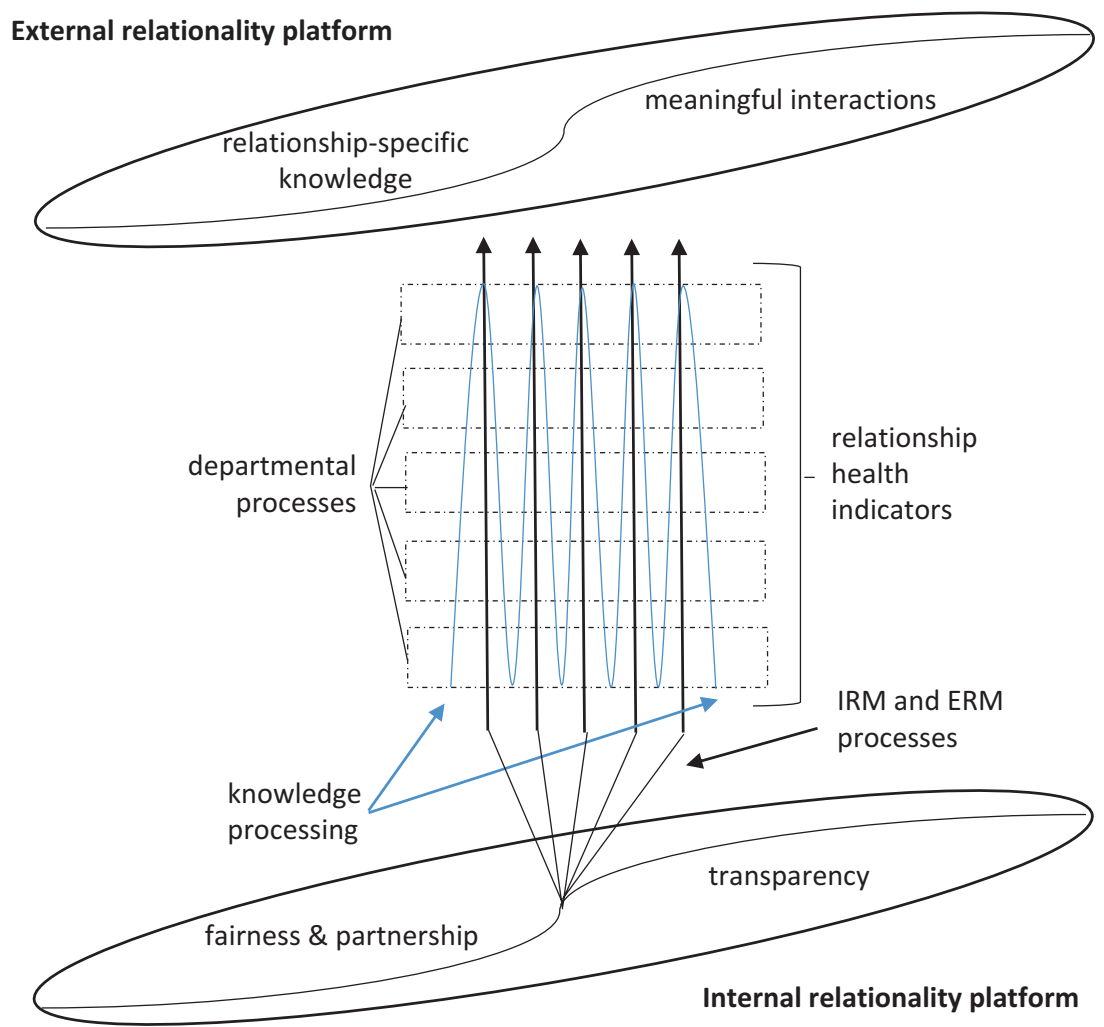

Fig. 3.8 Processual dimension in preliminary RM maturity model

impossible for such companies to offer a seamless and coherent customer service (Ahani et al. 2017; Harris et al. 2011; Jayachandran et al. 2005; Zand et al. 2018). Potential benefits of CRM systems range from time and cost reduction by automating tasks in the sales pipeline and in after-sales programmes and by streamlining administrative duties, to real-time access to insightful customer $360^{\circ}$ profiles enabling relational selling (Gentle 2002; Melville et al. 2004; Park et al. 2010). In addition, big data analytics activities, which work on separate systems but utilize the same customer data, improve company competitive advantage. Extracting, processing and providing knowledge for probabilistic algorithms is helpful in accurate targeting of marketing campaigns and enhancing customer profiles with 
advanced predictive modelling tools (e.g. 'next best action'; Erevelles et al. 2016; Hallikainen et al. 2019).

In an RM-mature company, digitalizing efforts should not only be applied to ERM processes. HRM automation may improve employee hiring, selection and development processes thanks to HR portfolio management, including existing and ex-employees, applicants and trainees (Chang et al. 2013). This is of high importance as, for example, for a newcomer to get fully on board takes from three to twelve months (Stibitz 2015). ICT may also help in decentralizing some standard administrative procedures by introducing employee self-service (Marler and Fisher 2013). This makes it possible to redefine the role of the HR function and to concentrate more on strategic activities such as sparking innovative projects or facilitating KM (Storey 2007).

Converting data into information and information into knowledge facilitated by ICT also includes communication (Lindner and Wald 2011; Teo et al. 2006). Collaborative CRM system functions enable file sharing and editing, online project management, discussions on forums, chat and improvement ideas submissions, and 'know-who' search. In fact, contemporary collaborative CRM systems use Social-CRM technology customized to internal use (Deszczyński 2018). Other social media technology instances include customer social profile data enrichment and sentiment research (Choudhury and Harrigan 2014; Simkin and Dibb 2013).

However, technologies are most effective when combined with other resources and processes (Chang et al. 2010). Moreover, even technologyoriented papers insist that human and organizational resources are more important than the ICT infrastructure itself (Keramati et al. 2010; Nguyen et al. 2007; Zerbino et al. 2018). In fact, poor ICT governance might actually depress relational communication by diverting resources to a botched CRM system implementation and evoking unfavourable sentiments among affected employees (Davis and Golicic 2010). Most commonly the failure lies not exactly within the ICT system, but in the way it was implemented in the organization (Jelinek 2013).

Successful CRM project management starts with top management championship practices. This means that CRM system implementation has to be communicated not solely as an ICT project, but as an integral part of corporate strategy and has to have the ongoing interest of its executive sponsor (Saini et al. 2010). Without such a commitment, which may sometimes involve using top management's authority to resolve disputes 
on competing interests, CRM system implementation projects are likely to fail (Kotorov 2003). A successful project also needs a project manager who is "... a combination technologist, business expert, drill sergeant, motivational speaker, politician, and psychologist" (Davenport 2000, p. 184). Their responsibility is managing communications and interaction with departments participating in the implementation, ensuring they build their own stake in the project and transfer the knowledge needed for optimal digitalization of business processes (Steel et al. 2013). The active participation of the vanguard of future users may significantly improve the system adoption rate by delivering practice-oriented tools and intuitive functions and by showcasing good system use practices, especially in the first weeks after its launch (Deszczyński 2011; Vella and Caruana 2012). With the ICT dimension, the preliminary RM maturity model is complete as presented in Fig. 3.9.

To conclude, the literature contains diversified vantage points of what RM-oriented companies should do. These varied approaches are now merged into the preliminary RM-maturity concept (refined theory-based RM business model), which can be briefly summed up as balancing focus on the portfolio of internal and external relationships. In particular, IRM is seen as crucial in creating the underlying substance for successful ERM. Both profit from a supportive corporate culture and inspiring mission, vision and corporate strategy, which are lived on a daily basis. ERM is made through some distinct dialogical, usually interdepartmental processes. These processes are knowledge-intensive, selective and measurable. Thus, RM-related sustainable competitive advantage emerges as a function of successful internal and external interactions, which create useful, consistently reapplied knowledge. Both need to be supported by powerful ICT tools, which is only possible if the ICT governance prioritizes human and business requirements over tactical technical goals.

With the literature review completed and the preliminary RM maturity model established, the next chapter will deal fully with the first main goal of this book by empirically testing the notion of RM maturity and verifying whether RM-mature firms possess the ability to achieve sustainable competitive advantage. 

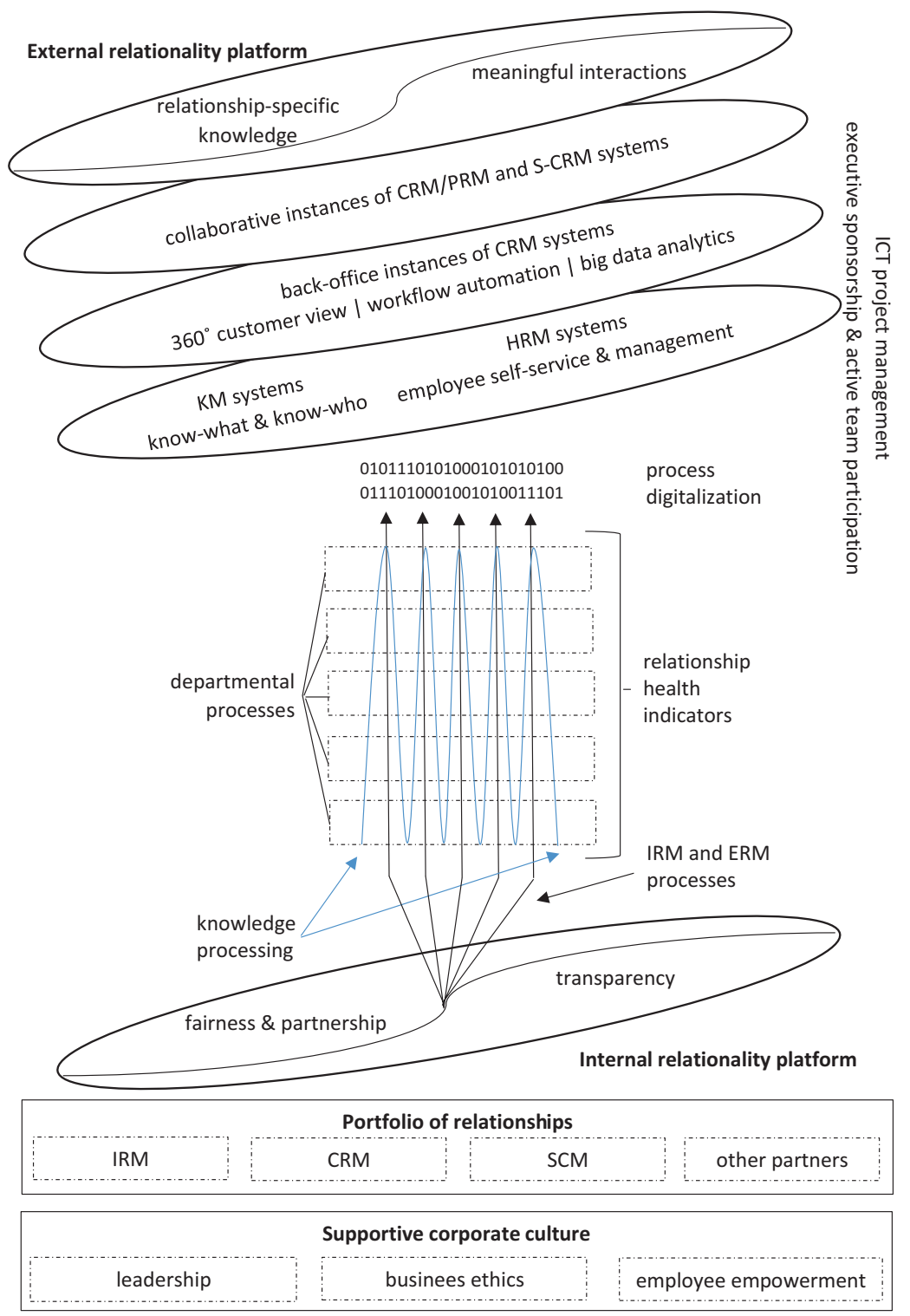

\section{SDL and RM-inspired mission, vision and strategic goals}

Fig. 3.9 Preliminary RM maturity model 


\section{REFERENCES}

Abrahamson, Eric. 1991. Managerial Fads and Fashions: The Diffusion and Rejection of Innovations. Academy of Management Review 16 (3): 586-612. https://doi.org/10.5465/amr.1991.4279484.

Ahani, Ali, Nor Zairah Ab. Rahim, and Mehrbakhsh Nilashi. 2017. Forecasting Social CRM Adoption in SMEs: A Combined SEM-Neural Network Method. Computers in Human Behavior 75: 560-578. https://doi.org/10.1016/j. chb.2017.05.032.

Aliyu, Olayemi Abdullateef, and Munyaradzi Wellington Nyadzayo. 2018. Reducing Employee Turnover Intention: A Customer Relationship Management Perspective. Journal of Strategic Marketing 26 (3): 241-257. https://doi.org/10.1080/0965254X.2016.1195864.

Altuntas Vural, Ceren. 2017. Service-Dominant Logic and Supply Chain Management: A Systematic Literature Review. Journal of Business \& Industrial Marketing 32 (8): 1109-1124. https://doi.org/10.1108/ JBIM-06-2015-0121.

Álvarez, Leticia Suárez, Rodolfo Vázquez Casielles, and Ana María Díaz Martín. 2010. Analysis of the Role of Complaint Management in the Context of Relationship Marketing. Journal of Marketing Management 27 (1-2): 143-164. https://doi.org/10.1080/02672571003719088.

Alvarez-Milán, Agarzelim, Reto Felix, Philipp A. Rauschnabel, and Christian Hinsch. 2018. Strategic Customer Engagement Marketing: A Decision Making Framework. Journal of Business Research 92: 61-70. https://doi. org/10.1016/j.jbusres.2018.07.017.

Arli, Denni, Carlos Bauer, and Robert W. Palmatier. 2018. Relational Selling: Past, Present and Future. Industrial Marketing Management 69: 169-184. https:// doi.org/10.1016/j.indmarman.2017.07.018.

Ashley, Christy, Stephanie M. Noble, Naveen Donthu, and Katherine N. Lemon. 2011. Why Customers Won't Relate: Obstacles to Relationship Marketing Engagement. Journal of Business Research 64 (7): 749-756. https://doi. org/10.1016/j.jbusres.2010.07.006.

Balaji, M.S., Sanjit Kumar Roy, and Khong Kok Wei. 2016. Does Relationship Communication Matter in B2C Service Relationships? Journal of Services Marketing 30 (2): 186-200. https://doi.org/10.1108/JSM-08-2014-0290.

Baran, Roger, and Robert Galka. 2017. Customer Relationship Management: The Foundation of Contemporary Marketing Strategy. 2nd ed. Abingdon: Routledge Publications.

Barney, Jay B. 1986. Organizational Culture: Can It Be a Source of Sustained Competitive Advantage? The Academy of Management Review 11 (3): 656-665. https://doi.org/10.2307/258317. 
Barsade, Sigal G., and Olivia A. O’Neill. 2016. 'Manage Your Emotional Culture'. Harvard Business Review, January 1. https://hbr.org/2016/01/ manage-your-emotional-culture

Baumol, William J., and Sue Anna Bafey Blackman. 1991. Perfect Markets and Easy Virtue, Business Ethics and the Invisible Hand. 1st ed. Oxford: Blackwell Publishing Ltd. https://www.abebooks.com/first-edition/Perfect-MarketsEasy-Virtue-Business-Ethics/22861690876/bd.

Bi, Qingqing. 2019. Cultivating Loyal Customers Through Online Customer Communities: A Psychological Contract Perspective. Journal of Business Research 103: 34-44. https://doi.org/10.1016/j.jbusres.2019.06.005.

Blau, Peter M. 1986. Exchange and Power in Social Life. 2nd ed. New Brunswick: Routledge.

Bock, Dora E., Stephanie M. Mangus, and Judith Anne Garretson Folse. 2016. The Road to Customer Loyalty Paved with Service Customization. Journal of Business Research 69 (10): 3923-3932. https://doi.org/10.1016/j. jbusres.2016.06.002.

Bratnicki, Mariusz, and Paweł Brzeziński. 2019. Wykorzystanie myślenia i działania do strategii przedsiębiorczej. Przegląd Organizacji 5: 9-15. https://doi. org/10.33141/po.2019.5.2.

Cambra-Fierro, Jesús, Iguácel Melero-Polo, and F. Javier Sese. 2016. Can Complaint-Handling Efforts Promote Customer Engagement? Service Business 10 (4): 847-866. https://doi.org/10.1007/s11628-015-0295-9.

Cameron, Kim S., and Robert E. Quinn. 2011. Diagnosing and Changing Organizational Culture: Based on the Competing Values Framework. 3rd ed. San Francisco: John Wiley \& Sons.

Carroll, Archie B. 1991. The Pyramid of Corporate Social Responsibility: Toward the Moral Management of Organizational Stakeholders. Business Horizons 34 (4): 39-49.

Chang, Woojung, Jeong Eun Park, and Seoil Chaiy. 2010. How Does CRM Technology Transform into Organizational Performance? A Mediating Role of Marketing Capability. Journal of Business Research 63 (8): 849-855. https:// doi.org/10.1016/j.jbusres.2009.07.003.

Chang, Song, Yaping Gong, Sean A. Way, and Liangding Jia. 2013. FlexibilityOriented HRM Systems, Absorptive Capacity, and Market Responsiveness and Firm Innovativeness. Journal of Management 39 (7): 1924-1951. https://doi. org/10.1177/0149206312466145.

Chari, Simos, Anssi Tarkiainen, and Hanna Salojärvi. 2016. Alternative Pathways to Utilizing Customer Knowledge: A Fuzzy-Set Qualitative Comparative Analysis. Journal of Business Research 69 (11): 5494-5499. https://doi. org/10.1016/j.jbusres.2016.04.160.

Charmaz, Kathy. 2004. Grounded Theory. In The SAGE Encyclopedia of Social Science Research Methods, ed. Michael S. Lewis, Alan Bryman, and Tim Futing 
Liao, 441-444. Thousand Oaks: SAGE Publications, Inc. https://doi. org/10.4135/9781412950589.

Chen, Injazz, and Karen Popovich. 2003. Understanding Customer Relationship Management (CRM): People, Process and Technology. Business Process Management Journal 9 (5): 672-688. https://doi.org/10.1108/14637150310496758.

Cheng, Lai-Yu, and Chih-Wei Yang. 2013. Conceptual Analysis and Implementation of an Integrated CRM System for Service Providers. Service Business 7 (2): 307-328. https://doi.org/10.1007/s11628-012-0160-z.

Cheung, Mee-Shew, Matthew B. Myers, and John T. Mentzer. 2011. The Value of Relational Learning in Global Buyer-Supplier Exchanges: A Dyadic Perspective and Test of the Pie-Sharing Premise. Strategic Management Journal 32 (10): 1061-1082. https://doi.org/10.1002/smj.926.

Chomiak-Orsa, I. 2016. Zarządzanie relacjami w organizacjach sieciowych. Organizacja i Zarzadzanie / Politechnika Slaska 90: 25-44.

Choudhury, Musfiq Mannan, and Paul Harrigan. 2014. CRM to Social CRM: The Integration of New Technologies into Customer Relationship Management. Journal of Strategic Marketing 22 (2): 149-176.

Collins, Jim, and Jerry I. Porras. 2002. Built to Last: Successful Habits of Visionary Companies. New York: HarperCollins.

Colombo, Massimo G., Marco Delmastro, and Larissa Rabbiosi. 2007. "High Performance" Work Practices, Decentralization, and Profitability: Evidence from Panel Data. Industrial and Corporate Change 16 (6): 1037-1067.

Conrad, Craig A., Gene Brown, and Harry A. Harmon. 1997. Customer Satisfaction and Corporate Culture: A Profile Deviation Analysis of a Relationship Marketing Outcome. Psychology \& Marketing 14 (7): 663-674. https://doi.org/10.1002/(SICI)1520-6793(199710)14:7<663:: AID-MAR2>3.0.CO;2-E.

Creed, W.E.Douglas. 2003. Voice Lessons: Tempered Radicalism and the Use of Voice and Silence*. Journal of Management Studies 40 (6): 1503-1536. https://doi.org/10.1111/1467-6486.00389.

Czakon, Wojciech. 2011. Paradygmat Sieciowy w Naukach o Zarządzaniu. Przeglad Organizacji 11 (5): 3-6.

- 2015. Podstawy metodologii badan w nankach o zarzadzaniu. 3rd ed. Ed. Wojciech Czakon. Warszawa: Oficyna a Wolters Kluwer business. https://ruj. uj.edu.pl/xmlui/handle/item/85236

Czakon, Wojciech, Patrycja Klimas, and Arkadiusz Kawa. 2019. Krótkowzroczność strategiczna - metodyczne aspekty systematycznego przeglądu literatury. Studia Oeconomica Posnaniensia 7 (2): 27-37. https://doi.org/10.18559/ SOEP.2019.2.2.

Davenport, Thomas H. 2000. Mission Critical: Realizing the Promise of Enterprise Systems. Boston: Harvard Business Press.

Davis, Donna F., and Susan L. Golicic. 2010. Gaining Comparative Advantage in Supply Chain Relationships: The Mediating Role of Market-Oriented IT 
Competence. Journal of the Academy of Marketing Science 38 (1): 56-70. https://doi.org/10.1007/s11747-008-0127-8.

Day, George S. 2003. Creating a Superior Customer-Relating Capability. MIT Sloan Management Review 44 (3): 77-82.

De Bruin, Tonia, Michael Rosemann, Ronald Freeze, and Uday Kaulkarni. 2005. Understanding the Main Phases of Developing a Maturity Assessment Model. In Australasian Conference on Information Systems (ACIS), ed. D. Bunker, B. Campbell, and J. Underwood, 8-19. Australasian Chapter of the Association for Information Systems. https://eprints.qut.edu.au/25152/.

de Ruyter, Ko, Debbie Isobel Keeling, and David Cox. 2019. CustomerSupplier Relationships in High Technology Markets 3.0. Industrial Marketing Management 79: 94-101. https://doi.org/10.1016/j. indmarman.2018.11.011.

Delpechitre, Duleeep, Lisa L. Beeler-Connelly, and Nawar N. Chaker. 2018. Customer Value Co-Creation Behavior: A Dyadic Exploration of the Influence of Salesperson Emotional Intelligence on Customer Participation and Citizenship Behavior. Journal of Business Research 92: 9-24. https://doi. org/10.1016/j.jbusres.2018.05.007.

Denison, Daniel R., and Aneil K. Mishra. 1995. Toward a Theory of Organizational Culture and Effectiveness. Organization Science 6 (2): 204-223.

Deszczyński, Bartosz. 2011. CRM. Strategia. System. Zarzadzanie zmiana: Jak uniknaćc btędów $i$ odnieśśc sukces wdrożenia. Warszawa: Wolters Kluwer.

- 2016a. The Impact of Opportunity Management on the Relationship Business Model (A Study in the Polish Housing Industry). Journal of Eastern European and Central Asian Research (JEECAR) 3 (2): 1-10. https://doi. org/10.15549/jeecar.v3i2.137.

- 2016b. The Maturity of Corporate Relationship Management. Gospodarka Narodowa 283 (3): 73-104. https://doi.org/10.33119/GN/100777.

- 2017. Word-Of-Mouth in Social Media. The Case of Polish Tourist Industry. International Journal of Management and Economics 53 (4): 93-114. https://doi.org/10.1515/ijme-2017-0028.

— 2018. Empowerment pracowników w przedsiębiorstwach branży usług biznesowych. Studia Oeconomica Posnaniensia 6, no. nr 4 Funkcjonowanie i rozwój sektora usług biznesowych w Europie Środkowej i Wschodniej-aspekty makro-i mikroekonomiczne: 113-143. https://doi.org/10.18559/ SOEP.2018.4.7.

Diefendorf, James M., Erin M. Richard, and Jixia Yang. 2008. Linking Emotion Regulation Strategies to Affective Events and Negative Emotions at Work. Journal of Vocational Behavior 73 (3): 498-508. https://doi.org/10.1016/j. jvb.2008.09.006. 
do Nascimento, Thaina T., Juliana B. Porto, and Catherine T. Kwantes. 2018. Transformational Leadership and Follower Proactivity in a Volunteer Workforce. Nonprofit Management and Leadership 28 (4): 565-576.

Dorotic, Matilda, Tammo H.A. Bijmolt, and Peter C. Verhoef. 2012. Loyalty Programmes: Current Knowledge and Research Directions. International Journal of Management Reviews 14 (3): 217-237. https://doi.org/10.1111/ j.1468-2370.2011.00314.x.

Doty, D. Harold, and William H. Glick. 1994. Typologies as a Unique Form of Theory Building: Toward Improved Understanding and Modeling. The Academy of Management Review 19 (2): 230-251. https://doi.org/10.2307/258704.

Dyer, Jeffrey H., and Harbir Singh. 1998. The Relational View: Cooperative Strategy and Sources of Interorganizational Competitive Advantage. The Academy of Management Review 23 (4): 660-679. https://doi.org/10.2307/259056.

Easterby-Smith, Mark, Richard Thorpe, and Paul R. Jackson. 2012. Management Research. London: SAGE.

Eisenhardt, Kathleen M., and Jeffrey A. Martin. 2000. Dynamic Capabilities: What Are They? Strategic Management Journal 21 (10-11): 1105-1121. https://doi.org/10.1002/1097-0266(200010/11)21:10/11<1105:: AID-SMJ133>3.0.CO;2-E.

Enz, Matias G., and Douglas M. Lambert. 2012. Using Cross-Functional, CrossFirm Teams to Co-Create Value: The Role of Financial Measures. Industrial Marketing Management, IMPASIA 2010, 41 (3): 495-507. https://doi. org/10.1016/j.indmarman.2011.06.041.

Erevelles, Sunil, Nobuyuki Fukawa, and Linda Swayne. 2016. Big Data Consumer Analytics and the Transformation of Marketing. Journal of Business Research 69 (2): 897-904. https://doi.org/10.1016/j.jbusres.2015.07.001.

Eveland, Vicki Blakney, Tammy Neal Crutchfield, and Ania Izabela Rynarzewska. 2018. Developing a Consumer Relationship Model of Corporate Social Performance. Journal of Consumer Marketing 35 (5): 543-554. https://doi. org/10.1108/JCM-07-2017-2287.

Fink, Arlene. 2010. Conducting Research Literature Reviews: From the Internet to Paper. 3rd ed. Los Angeles: SAGE.

FitzPatrick, Mary, Richard J. Varey, Christian Grönroos, and Janet Davey. 2015. Relationality in the Service Logic of Value Creation. Journal of Services Marketing 29 (6/7): 463-471. https://doi.org/10.1108/JSM-01-20150038 .

Fonfara, Krzysztof. 2014. Marketing Partnerski Na Rynku Przedsiębiorstw. Warszawa: PWE.

Forkmann, Sebastian, Stephan C. Henneberg, Peter Naudé, and Maciej Mitrega. 2016. Supplier Relationship Management Capability: A Qualification and Extension. Industrial Marketing Management 57: 185-200. https://doi. org/10.1016/j.indmarman.2016.02.003. 
Galvão, Marcella Brito, Raíssa Corrêa de Carvalho, Lucas Ambrósio Bezerra de Oliveira, and Denise Dumke de Medeiros. 2018. Customer Loyalty Approach Based on CRM for SMEs. Journal of Business \& Industrial Marketing, June 4. https://doi.org/10.1108/JBIM-07-2017-0166

Gentle, Michael. 2002. The CRM Project Management Handbook: Building Realistic Expectations and Managing Risk. London/Sterling. http://search. ebscohost.com $/ \operatorname{login}$. aspx?direct $=$ true $\& \mathrm{db}=\mathrm{eoh} \& \mathrm{AN}=0658504 \& \mathrm{lang}=\mathrm{pl} \&$ site $=$ ehost-live

Giannakis, Damianos, Michael J. Harker, and Tom Baum. 2015. Human Resource Management, Services and Relationship Marketing: The Potential for CrossFertilisation. Journal of Strategic Marketing 23 (6): 526-542. https://doi. org/10.1080/0965254X.2014.1001862.

Gough, David, and Michelle Richardson. 2018. Systematic Reviews. In Advanced Research Methodsfor Applied Psychology: Design, Analysis and Reporting, ed. Paula Brough. London: Routledge. https://doi.org/10.4324/9781315517971-8.

Gounaris, Spiros P. 2006. Internal-Market Orientation and Its Measurement. Journal of Business Research 59 (4): 432-448.

Grace, Debra, and Joseph Lo Iacono. 2015. Value Creation: An Internal Customers' Perspective. Journal of Services Marketing 29 (6/7): 560-570. https://doi.org/10.1108/JSM-09-2014-0311.

Grandey, Alicia A. 2003. When "The Show Must Go On": Surface Acting and Deep Acting as Determinants of Emotional Exhaustion and Peer-Rated Service Delivery. Academy of Management Journal 46 (1): 86-96. https://doi. org/10.5465/30040678.

Grönroos, Christian. 2011a. A Service Perspective on Business Relationships: The Value Creation, Interaction and Marketing Interface. Industrial Marketing Management, Special issue on Service-Dominant Logic in Business Markets, 40 (2): 240-247. https://doi.org/10.1016/j.indmarman.2010.06.036.

- 2011 b. Value Co-Creation in Service Logic: A Critical Analysis. Marketing Theory 11 (3): 279-301. https://doi.org/10.1177/1470593111408177.

- 2016. Service Management and Marketing: Managing the Service Profit Logic. 4th ed. Chichester: Wiley. https://www.wiley.com/en-us/Service+Man agement+and+Marketing $\% 3 \mathrm{~A}+$ Managing + the + Service + Profit + Logic $\% 2 \mathrm{C}+4$ th + Edition-p-9781118921449.

- 2017. Relationship Marketing Readiness: Theoretical Background and Measurement Directions. Journal of Services Marketing 31 (3): 218-225. https://doi.org/10.1108/JSM-02-2017-0056.

Grunig, James E. 2008. Excellence in Public Relations and Communication Management. New York: Routledge.

Guenzi, Paolo, Catherine Pardo, and Laurent Georges. 2007. Relational Selling Strategy and Key Account Managers' Relational Behaviors: An Exploratory Study. Industrial Marketing Management 36 (1): 121-133. 
Guesalaga, Rodrigo, and Wesley Johnston. 2010. What's Next in Key Account Management Research? Building the Bridge Between the Academic Literature and the Practitioners' Priorities. Industrial Marketing Management, Selling and Sales Management, 39 (7): 1063-1068. https://doi.org/10.1016/j. indmarman.2009.12.008.

Gummesson, Evert. 1999. Total Relationship Marketing: Experimenting With a Synthesis of Research Frontiers. Australasian Marketing Journal (AMJ) 7 (1): 72-85. https://doi.org/10.1016/S1441-3582(99)70204-1.

- 2012. Total Relationship Marketing: Marketing Strategy Moving from the 4Ps-Product, Price, Promotion, Place-of Traditional Marketing Management to the 30Rs-the Thirty Relationships-of a New Marketing Paradigm. Abingdon: Routledge. https://books.google.pl/books?id=x-iZOqS9leAC.

- 2017a. From Relationship Marketing to Total Relationship Marketing and Beyond. Journal of Services Marketing 31 (1): 16-19. https://doi. org/10.1108/JSM-11-2016-0398.

- 2017b. Total Relationship Marketing. 4th ed. Routledge: Abingdon.

Gummesson, Evert, and Cristina Mele. 2010. Marketing as Value Co-Creation Through Network Interaction and Resource Integration. Journal of Business Market Management 4 (4): 181-198. https://doi.org/10.1007/ s12087-010-0044-2.

Hajli, Nick, Mohana Shanmugam, Savvas Papagiannidis, Debra Zahay, and MarieOdile Richard. 2017. Branding Co-Creation with Members of Online Brand Communities. Journal of Business Research 70: 136-144. https://doi. org/10.1016/j.jbusres.2016.08.026.

Hallikainen, Heli, Emma Savimäki, and Tommi Laukkanen. 2019. Fostering B2B Sales with Customer Big Data Analytics. Industrial Marketing Management, December 24. https://doi.org/10.1016/j.indmarman.2019.12.005.

Harris, Jeanne G., Elizabeth Craig, and David A. Light. 2011. Talent and Analytics: New Approaches, Higher ROI. Journal of Business Strategy 32 (6): 4-13. https://doi.org/10.1108/02756661111180087.

Hartline, Michael D., James G. Maxham, and Daryl O. McKee. 2000. Corridors of Influence in the Dissemination of Customer-Oriented Strategy to Customer Contact Service Employees. Journal of Marketing 64 (2): 35-50. https://doi. org/10.1509/jmkg.64.2.35.18001.

Hawkins, David, and Bob Little. 2011. Embedding Collaboration through Standards - Part 1. Industrial e Commercial Training 43 (2): 106-112.

Heavey, Ciaran, Zeki Simsek, Christina Kyprianou, and Marten Risius. 2020. How Do Strategic Leaders Engage with Social Media? A Theoretical Framework for Research and Practice. Strategic Management Journal 41 (8): 1490-1527. https://doi.org/10.1002/smj.3156. 
Herington, Carmel, Lester W. Johnson, and Don Scott. 2009. Firm-Employee Relationship StrengthA Conceptual Model. Journal of Business Research 62 (11): 1096-1107.

Hogan, Suellen J., and Leonard V. Coote. 2014. Organizational Culture, Innovation, and Performance: A Test of Schein's Model. Journal of Business Research 67 (8): 1609-1621. https://doi.org/10.1016/j.jbusres.2013. 09.007.

Hollebeek, Linda D., Rajendra K. Srivastava, and Tom Chen. 2019. S-D LogicInformed Customer Engagement: Integrative Framework, Revised Fundamental Propositions, and Application to CRM. Journal of the Academy of Marketing Science 47 (1): 161-185. https://doi.org/10.1007/s11747-016-0494-5.

Holm, Morten, V. Kumar, and Carsten Rohde. 2012. Measuring Customer Profitability in Complex Environments: An Interdisciplinary Contingency Framework. Journal of the Academy of Marketing Science 40 (3): 387-401. https://doi.org/10.1007/s11747-011-0263-4.

Homburg, Christian, Andreas Fürst, and Nicole Koschate. 2010. On the Importance of Complaint Handling Design: A Multi-Level Analysis of the Impact in Specific Complaint Situations. Journal of the Academy of Marketing Science 38 (3): 265-287. https://doi.org/10.1007/s11747-009-0172-y.

Huang, Min-Hsin. 2015. The Influence of Relationship Marketing Investments on Customer Gratitude in Retailing. Journal of Business Research 68 (6): 1318-1323. https://doi.org/10.1016/j.jbusres.2014.12.001.

Hwang, Jiyoung, and Jay Kandampully. 2015. Embracing CSR in Pro-Social Relationship Marketing Program: Understanding Driving Forces of Positive Consumer Responses. Journal of Services Marketing 29 (5): 344-353. https:// doi.org/10.1108/JSM-04-2014-0118.

Ichniowski, Casey, Kathryn Shaw, and Giovanna Prennushi. 1997. The Effects of Human Resource Management Practices on Productivity: A Study of Steel Finishing Lines. American Economic Review 87 (3): 291-313.

Jakubów, Leon. 2016. Ewolucja Planowania Rozwoju Przedsiębiorstwa. Evolution in the Enterprise Development Planning. Prace Naukowe Uniwersytetu Ekonomicznego we Wroctawiu 444: 211-221.

Jayachandran, Satish, Kelly Hewett, and Peter Kaufman. 2004. Customer Response Capability in a Sense-and-Respond Era: The Role of Customer Knowledge Process. Journal of the Academy of Marketing Science 32 (3): 219-233. https:// doi.org/10.1177/0092070304263334.

Jayachandran, Satish, Subhash Sharma, Peter Kaufman, and Pushkala Raman. 2005. The Role of Relational Information Processes and Technology Use in Customer Relationship Management. Journal of Marketing 69 (4): 177-192. https://doi.org/10.1509/jmkg.2005.69.4.177.

Jelinek, Ronald. 2013. All Pain, No Gain? Why Adopting Sales Force Automation Tools Is Insufficient for Performance Improvement. Business Horizons 56 (5): 635-642. https://doi.org/10.1016/j.bushor.2013.06.002. 
Johnson, Michael D., and Fred Selnes. 2004. Customer Portfolio Management: Toward a Dynamic Theory of Exchange Relationships. Journal of Marketing 68 (2): 1-17. https://doi.org/10.1509/jmkg.68.2.1.27786.

Jones, Thomas O., and W. Earl Sasser Jr. 1995. Why Satisfied Customers Defect. Harvard Business Review, November 1. https://hbr.org/1995/11/ why-satisfied-customers-defect

Kaski, Timo, Jarkko Niemi, and Ellen Pullins. 2018. Rapport Building in Authentic B2B Sales Interaction. Industrial Marketing Management 69: 235-252. https://doi.org/10.1016/j.indmarman.2017.08.019.

Kazanjian, Robert K., and Robert Drazin. 1989. An Empirical Test of a Stage of Growth Progression Model. Management Science 35 (12): 1489-1503. https://doi.org/10.1287/mnsc.35.12.1489.

Keramati, Abbas, Hamed Mehrabi, and Navid Mojir. 2010. A Process-Oriented Perspective on Customer Relationship Management and Organizational Performance: An Empirical Investigation. Industrial Marketing Management, Selling and Sales Management 39 (7): 1170-1185. https://doi.org/10.1016/j. indmarman.2010.02.001.

Ketokivi, Mikko, and Saku Mantere. 2010. Two Strategies for Inductive Reasoning in Organizational Research. Academy of Management Review 35 (2): 315-333. https://doi.org/10.5465/amr.35.2.zok315.

Killian, Ginger, and Kristy McManus. 2015. A Marketing Communications Approach for the Digital Era: Managerial Guidelines for Social Media Integration. Business Horizons 58 (5): 539-549. https://doi.org/10.1016/j. bushor.2015.05.006.

Kim Jean Lee, Siew, and Kelvin Yu. 2004. Corporate Culture and Organizational Performance. Journal of Managerial Psychology 19 (4): 340-359. https://doi. org/10.1108/02683940410537927.

Kotorov, Rado. 2003. Customer Relationship Management: Strategic Lessons and Future Directions. Business Process Management Journal 9 (5): 566-571. https://doi.org/10.1108/14637150310496686.

Kotter, John P., and James L. Heskett. 2011. Corporate Culture and Performance. Reprint edition. New York: Free Press.

Kumar, Vineet, and Werner J. Reinartz. 2006. Customer Relationship Management: A Databased Approach. Hoboken: Wiley \& Sons.

Kumar, V., Bharath Rajan, Shaphali Gupta, and Ilaria Dalla Pozza. 2019. Customer Engagement in Service. Journal of the Academy of Marketing Science 47 (1): 138-160. https://doi.org/10.1007/s11747-017-0565-2.

L'Etang, Jacquie. 1994. Public Relations and Corporate Social Responsibility: Some Issues Arising. Journal of Business Ethics 13 (2): 111-123. https://doi. org/10.1007/BF00881580.

Lacey, Russell, Pamela A. Kennett-Hensel, and Chris Manolis. 2015. Is Corporate Social Responsibility a Motivator or Hygiene Factor? Insights into Its Bivalent 
Nature. Journal of the Academy of Marketing Science 43 (3): 315-332. https:// doi.org/10.1007/s11747-014-0390-9.

Lambe, C. Jay, C. Michael Wittmann, and Robert E. Spekman. 2001. Social Exchange Theory and Research on Business-to-Business Relational Exchange. Journal of Business-to-Business Marketing 8 (3): 1.

Lambert, Douglas M. 2008. Supply Chain Management: Processes, Partnerships, Performance. Sarasota: Supply Chain Management Institute.

- 2010. Customer Relationship Management as a Business Process. Journal of Business \& Industrial Marketing 25 (1): 4-17. https://doi. org/10.1108/08858621011009119.

Lichtarski, Jan. 2015. Praktyczny Wymiar Nauk o Zarzaddzaniu. Warszawa: Polskie Wydawnictwo Ekonomiczne.

Lindgreen, Adam, and Valérie Swaen. 2010. Corporate Social Responsibility. International Journal of Management Reviews 12 (1): 1-7. https://doi. org/10.1111/j.1468-2370.2009.00277.x.

Lindner, Frank, and Andreas Wald. 2011. Success Factors of Knowledge Management in Temporary Organizations. International Journal of Project Management, Complexities in Managing Mega Construction Projects, 29 (7): 877-888. https://doi.org/10.1016/j.ijproman.2010.09.003.

Ling-yee, Li. 2011. 'Marketing Metrics' Usage: Its Predictors and Implications for Customer Relationship Management. Industrial Marketing Management, Business-to-Business Marketing in the BRIC Countries, 40 (1): 139-148. https://doi.org/10.1016/j.indmarman.2010.09.002.

Lusch, Robert F., Stephen L. Vargo, and Mohan Tanniru. 2010. Service, Value Networks and Learning. Journal of the Academy of Marketing Science 38 (1): 19-31. https://doi.org/10.1007/s11747-008-0131-z.

Luu, Ngoc, Liem Viet Ngo, and Jack Cadeaux. 2018. Value Synergy and Value Asymmetry in Relationship Marketing Programs. Industrial Marketing Management 68: 165-176. https://doi.org/10.1016/j. indmarman.2017.10.011.

Ma, Baolong, Xiaofei Li, and Lin Zhang. 2018. The Effects of Loyalty Programs in Services - A Double-Edged Sword? Journal of Services Marketing 32 (3): 300-310. https://doi.org/10.1108/JSM-06-2016-0227.

Macdonald, Emma K., Hugh Wilson, Veronica Martinez, and Amir Toossi. 2011. Assessing Value-in-Use: A Conceptual Framework and Exploratory Study. Industrial Marketing Management, Service and Solution Innovation, 40 (5): 671-682. https://doi.org/10.1016/j.indmarman.2011.05.006.

Madhavaram, Sreedhar, Elad Granot, and Vishag Badrinarayanan. 2014. Relationship Marketing Strategy: An Operant Resource Perspective. Journal of Business \& Industrial Marketing, April 1. https://doi.org/10.1108/ JBIM-02-2013-0049.

Maher, Patrick. 1996. The Hole in the Ground of Induction. Australasian Journal ofPhilosophy74(3):423-432.https://doi.org/10.1080/00048409612347411. 
Mangold, W. Glynn, and Sandra Jeanquart Miles. 2007. The Employee Brand: Is Yours an All-Star? Business Horizons 50 (5): 423-433.

Marcos-Cuevas, Javier, Satu Nätti, Teea Palo, and Lynette J. Ryals. 2014. Implementing Key Account Management: Intraorganizational Practices and Associated Dilemmas. Industrial Marketing Management 43 (7): 1216-1224. https://doi.org/10.1016/j.indmarman.2014.06.009.

Marler, Janet H., and Sandra L. Fisher. 2013. An Evidence-Based Review of e-HRM and Strategic Human Resource Management. Human Resource Management Review, Emerging Issues in Theory and Research on Electronic Human Resource Management (eHRM), 23 (1): 18-36. https://doi. org/10.1016/j.hrmr.2012.06.002.

Martelo, Silvia, Carmen Barroso, and Gabriel Cepeda. 2013. The Use of Organizational Capabilities to Increase Customer Value. Journal of Business Research, Strategic Thinking in Marketing, 66 (10): 2042-2050. https://doi. org/10.1016/j.jbusres.2013.02.030.

Mauboussin, Michael J. 2012. The True Measures of Success. Harvard Business Review, October 1. https://hbr.org/2012/10/the-true-measures-of-success

Melancon, Joanna Phillips, and Vassilis Dalakas. 2018. Consumer Social Voice in the Age of Social Media: Segmentation Profiles and Relationship Marketing Strategies. Business Horizons 61 (1): 157-167. https://doi.org/10.1016/j. bushor.2017.09.015.

Melville, Nigel, Kenneth L. Kraemer, and Vijay Gurbaxani. 2004. Review: Information Technology and Organizational Performance: An Integrative Model of IT Business Value. MIS Quarterly 28: 283-322. https://doi. org/10.2307/25148636.

Men, Linjuan Rita. 2014. Strategic Internal Communication: Transformational Leadership, Communication Channels, and Employee Satisfaction. Management Communication Quarterly 28 (2): 264-284.

Men, Linjuan Rita, and Katy L. Robinson. 2018. It's About How Employees Feel! Examining the Impact of Emotional Culture on Employee-Organization Relationships. Corporate Communications: An International Journal 23 (4): 470-491. https://doi.org/10.1108/CCIJ-05-2018-0065.

Mettler, Tobias. 2011. Maturity Assessment Models: A Design Science Research Approach. International Journal of Society Systems Science (IJSSS) 3 $(1 / 2): 81-98$.

Minkiewicz, Joanna, Kerrie Bridson, and Jody Evans. 2016. Co-Production of Service Experiences: Insights from the Cultural Sector. Journal of Services Marketing 30 (7): 749-761. https://doi.org/10.1108/JSM-04-2015-0156.

Miocevic, Dario, and Biljana Crnjak-Karanovic. 2012. The Mediating Role of Key Supplier Relationship Management Practices on Supply Chain Orientation the Organizational Buying Effectiveness Link. Industrial Marketing Management 41 (1): 115-124. https://doi.org/10.1016/j.indmarman.2011.11.015. 
Morgan, Robert M., and Shelby D. Hunt. 1994. The Commitment-Trust Theory of Relationship Marketing. Journal of Marketing 58 (3): 20-38. https://doi. org/10.1177/002224299405800302.

Neslin, Scott A., Gail Ayala Taylor, Kimberly D. Grantham, and Kimberly R. McNeil. 2013. Overcoming the "Recency Trap" in Customer Relationship Management. Journal of the Academy of Marketing Science 41 (3): 320-337. https://doi.org/10.1007/s11747-012-0312-7.

Ngo, Liem Viet, and Aron O'Cass. 2013. Innovation and Business Success: The Mediating Role of Customer Participation. Journal of Business Research, Recent Advances in Globalization, Culture and Marketing Strategy, 66 (8): 1134-1142. https://doi.org/10.1016/j.jbusres.2012.03.009.

Nguyen, ThuyUyen H., Joseph S. Sherif, and Michael Newby. 2007. Strategies for Successful CRM Implementation. Information Management \& Computer Security 15 (2): 102-115. https://doi.org/10.1108/09685220710748001.

Oghazi, Pejvak, Fakhreddin Fakhrai Rad, Ghasem Zaefarian, Hooshang M. Beheshti, and Sina Mortazavi. 2016. Unity Is Strength: A Study of Supplier Relationship Management Integration. Journal of Business Research 69 (11): 4804-4810. https://doi.org/10.1016/j.jbusres.2016.04.034.

Ohiomah, Alhassan, Pavel Andreev, Morad Benyoucef, and David Hood. 2019. The Role of Lead Management Systems in Inside Sales Performance. Journal of Business Research 102: 163-177.

Orr, Linda M., Victoria D. Bush, and Douglas W. Vorhies. 2011. Leveraging Firm-Level Marketing Capabilities with Marketing Employee Development. Journal of Business Research 64 (10): 1074-1081. https://doi.org/10.1016/j. jbusres.2010.11.003.

Park, Jeong Eun, Juyoung Kim, Alan J. Dubinsky, and Hyunju Lee. 2010. How Does Sales Force Automation Influence Relationship Quality and Performance? The Mediating Roles of Learning and Selling Behaviors. Industrial Marketing Management, Selling and Sales Management, 39 (7): 1128-1138. https://doi. org/10.1016/j.indmarman.2009.11.003.

Paulk, M.C., B. Curtis, M.B. Chrissis, and C.V. Weber. 1993. Capability Maturity Model, Version 1.1. IEEE Software 10 (4): 18-27. https://doi. org/10.1109/52.219617.

Payne, Adrian, and Pennie Frow. 2005. A Strategic Framework for Customer Relationship Management. Journal of Marketing 69 (4): 167-176. https:// doi.org/10.1509/jmkg.2005.69.4.167.

-. 2013. Strategic Customer Management: Integrating Relationship Marketing and CRM. Cambridge University Press.

- 2016. Customer Relationship Management: Strategy and Implementation. In The Marketing Book, ed. Michael J. Baker and Susan Hart, 439-466. London: Routledge. https://doi.org/10.4324/9781315890005-28. 
Payne, Adrian, Kaj Storbacka, Pennie Frow, and Simon Knox. 2009. Co-Creating Brands: Diagnosing and Designing the Relationship Experience. Journal of Business Research, Advances in Brand Management, 62 (3): 379-389. https:// doi.org/10.1016/j.jbusres.2008.05.013.

Peppers, Don, and Martha Rogers. 2013. Extreme Trust: The New Competitive Advantage. Strategy and Leadership 41 (6): 31-34. https://doi.org/10.1108/ SL-07-2013-0054.

Pöppelbuß, Jens, and Maximilian Röglinger. 2011. What Makes a Useful Maturity Model? A Framework of General Design Principles for Maturity Models and Its Demosntration in Business Process Management. In ECIS Proceedings, 28, 13. European Conference on Information Systems (ECIS).

Pozza, Dalla Ilaria, Oliver Goetz, and Jean Michel Sahut. 2018. Implementation Effects in the Relationship Between CRM and Its Performance. Journal of Business Research 89: 391-403. https://doi.org/10.1016/j.jbusres.2018.02.004.

Prahalad, C.K., and Gary Hamel. 1994. Strategy as a Field of Study: Why Search for a New Paradigm? Strategic Management Journal 15 (S2): 5-16. https:// doi.org/10.1002/smj.4250151002.

Preikschas, Michael W., Pablo Cabanelas, Klaus Rüdiger, and Jesús F. Lampón. 2017. Value Co-Creation, Dynamic Capabilities and Customer Retention in Industrial Markets. Journal of Business \& Industrial Marketing 3. https://doi. org/10.1108/JBIM-10-2014-0215.

Prior, Daniel D. 2012. The Effects of Buyer-supplier Relationships on Buyer Competitiveness. Journal of Business o Industrial Marketing 27 (2): 100-114. https://doi.org/10.1108/08858621211196976.

Quinn, Robert E., and John Rohrbaugh. 1983. A Spatial Model of Effectiveness Criteria: Towards a Competing Values Approach to Organizational Analysis. Management Science 29 (3): 363-377.

Ramani, Girish, and V. Kumar. 2008. Interaction Orientation and Firm Performance. Journal of Marketing 72 (1): 27-45. https://doi.org/10.1509/ jmkg.72.1.027.

Reichheld, Frederick. 2001. Loyalty Rules!: How Today's Leaders Build Lasting Relationships. Boston: Harvard Business School Press. https://books.google. $\mathrm{pl} /$ books?hl=pl\&lr=\&id=oT31L0QdWiwC\&oi=fnd\&pg=PPl \&dq=reichhel $\mathrm{d}+2001+$ loyalty\&ots=zD3RjjPbTW\&sig=cYD89k0tVodkW2Tcl HhiTuZhacc \&redir_esc=y\#v=onepage \&q=reichheld $\% 202001 \% 20$ loyalty\&f=false.

- 2006. The Microeconomics of Customer Relationships. MIT Sloan Management Review 47 (2): 72-78.

Reinartz, Werner, Manfred Krafft, and Wayne D. Hoyer. 2004. The Customer Relationship Management Process: Its Measurement and Impact on Performance. Journal of Marketing Research. https://doi.org/10.1509/ jmkr.41.3.293.35991. 
Röglinger, Maximilian, Jens Pöppelbuß, and Jörg Becker. 2012. Maturity Models in Business Process Management. Business Process Management Journal 18 (2): 328-346. https://doi.org/10.1108/14637151211225225.

Rosemann, Michael. 2006. Potential Pitfalls of Process Modeling: Part A. Business Process Management Journal 12 (2): 249-254. https://doi. org/10.1108/14637150610657567.

Rosemann, Michael, and Tonia de Bruin. 2005. Application of a Holistic Model for Determining BPM Maturity. BP Trends 2: 1-21.

Roy, Sanjit Kumar, Gul Butaney, Harjit Sekhon, and Bhupin Butaney. 2014. Word-of-Mouth and Viral Marketing Activity of the On-Line Consumer: The Role of Loyalty Chain Stages Theory. Journal of Strategic Marketing 22 (6): 494-512.

Russo-Spena, Tiziana, and Cristina Mele. 2012. "Five Co-s" in Innovating: A Practice-based View'. Edited by Evert Gummesson, Cristina Mele, and Francesco Polese. Journal of Service Management 23 (4): 527-553. https:// doi.org/10.1108/09564231211260404.

Ryan, Richard M., and Edward L. Deci. 2000. Self-determination theory and the facilitation of intrinsic motivation, social development, and well-being. American Psychologist, 55(1), 68-78. https://doi.org/10.1037/0003-066X.55.1.68.

- 2017. Self-Determination Theory: Basic Psychological Needs in Motivation, Development, and Wellness. New York: Guilford Publications.

Sabnis, Gaurav, Sharmila C. Chatterjee, Rajdeep Grewal, and Gary L. Lilien. 2013. The Sales Lead Black Hole: On Sales Reps' Follow-Up of Marketing Leads. Journal of Marketing 77 (1): 52-67. https://doi.org/10.1509/jm.10.0047.

Saini, Amit, Rajdeep Grewal, and Jean L. Johnson. 2010. Putting Market-Facing Technology to Work: Organizational Drivers of CRM Performance. Marketing Letters 21 (4): 365-383. https://doi.org/10.1007/s11002-009-9096-z.

Sasidharan Dhanesh, Ganga. 2012. The View from Within: Internal Publics and CSR. Journal of Communication Management 16 (1): 39-58. https://doi. org/10.1108/13632541211197987.

Schein, Edgar H. 1990. Organizational Culture. American Psychologist 45 (2): 109-119. https://doi.org/10.1037/0003-066X.45.2.109.

Scherer, Klaus. 1997. Profiles of Emotion-Antecedent Appraisal: Testing Theoretical Predictions across Cultures. Cognition and Emotion 11 (2): 113-150. https://doi.org/10.1080/026999397379962.

Schuler, Douglas A., and Margaret Cording. 2006. A Corporate Social Performance-Corporate Financial Performance Behavioral Model for Consumers. Academy of Management Review 31 (3): 540-558. https://doi. org/10.5465/amr.2006.21318916.

Schwalbe, Kathy. 2008. Information Technology Project Management, Reprint. 5th ed. Boston: Thomson Course Technology. 
Sheth, Jagdish N. 2017. Revitalizing Relationship Marketing. Journal of Services Marketing 31 (1): 6-10. https://doi.org/10.1108/JSM-11-2016-0397.

Shi, Linda Hui, and Tao (Tony) Gao. 2016. Performance Effects of Global Account Coordination Mechanisms: An Integrative Study of Boundary Conditions. Journal of International Marketing, June 1. https://doi. org/10.1509/jim.15.0103.

Simkin, Lyndon, and Sally Dibb. 2013. Social Media's Impact on Market Segmentation and CRM. Journal of Strategic Marketing 21 (5): 391-393.

Singh, Shweta, and Sumit Singh. 2016. Accounting for Risk in the Traditional RFM Approach. Management Research Review 39 (2): 215-234.

Slater, Stanley F. 1997. Developing a Customer Value-Based Theory of the Firm. Journal of the Academy of Marketing Science 25 (2): 162-167. https://doi. org/10.1007/BF02894352.

Slater, Stanley F., Eric M. Olson, and Carol Finnegan. 2011. Business Strategy, Marketing Organization Culture, and Performance. Marketing Letters 22 (3): 227-242. https://doi.org/10.1007/s11002-010-9122-1.

Smith, Timothy M., Srinath Gopalakrishna, and Rabikar Chatterjee. 2006. A Three-Stage Model of Integrated Marketing Communications at the MarketingSales Interface. Journal of Marketing Research 43 (4): 564-579. https://doi. org/10.1509/jmkr.43.4.564.

Sprenger, Jan. 2011. Hypothetico-Deductive Confirmation. Philosophy Compass 6 (7): 497-508. https://doi.org/10.1111/j.1747-9991.2011.00409.x.

Sriramesh, K., James E. Grunig, and David M. Dozier. 1996. Observation and Measurement of Two Dimensions of Organizational Culture and Their Relationship to Public Relations. Journal of Public Relations Research 8 (4): 229-261. https://doi.org/10.1207/s1532754xjprr0804_02.

Steel, Marion, Chris Dubelaar, and Michael T. Ewing. 2013. Developing Customised CRM Projects: The Role of Industry Norms, Organisational Context and Customer Expectations on CRM Implementation. Industrial Marketing Management 42 (8): 1328-1344. https://doi.org/10.1016/j. indmarman.2012.08.009.

Stibitz, Sara. 2015. How to Get a New Employee Up to Speed. Harvard Business Review Digital Articles 22: 2-5.

Storbacka Kaj, Frow Pennie, Nenonen Suvi, and Payne Adrian. 2012. Designing Business Models for Value Co-Creation. Edited by Stephen L. Vargo and Robert F. Lusch. Special Issue - Toward a Better Understanding of the Role of Value in Markets and Marketing, Review of Marketing Research, 9: 51-78. https://doi.org/10.1108/S1548-6435(2012)0000009007.

Storey, John. 2007. Human Resource Management: A Critical Text. 3rd ed. London: Thomson Learning. http://edu.cengage.co.uk/catalogue/product. aspx?isbn=1844806154. 
Strauss, Anselm L., and Juliet M. Corbin. 1998. Basics of Qualitative Research: Techniques and Procedures for Developing Grounded Theory. 2nd ed. Thousand Oaks: Sage Publications.

Sull, Donald Norman, and Kathleen M. Eisenhardt. 2015. Simple Rules: How to Thrive in a Complex World. Boston: Houghton Mifflin Harcourt.

Svendsen, Freng. 2011. Marketing Strategy and Customer Involvement in Product Development. European Journal of Marketing 45 (4): 513-530. https://doi. org/10.1108/03090561111111316.

Tarhan, Ayca, Oktay Turetken, and Hajo A. Reijers. 2016. Business Process Maturity Models: A Systematic Literature Review. Information and Software Technology 75: 122-134. https://doi.org/10.1016/j.infsof.2016.01.010.

Teece, David J., Gary Pisano, and Amy Shuen. 1997. Dynamic Capabilities and Strategic Management. Strategic Management Journal 18 (7): 509-533. https://doi.org/10.1002/(SICI)1097-0266(199708)18:7<509:: AID-SMJ882>3.0.CO;2-Z.

Teneta-Skwiercz, Dorota. 2008. Wymiar Etyczny w Funkcjonowaniu Współczesnego Przedsiębiorstwa. Edited by Jan Lichtarski. Prace Naukowe Uniwersytetu Ekonomicznego We Wroctawiu 34: 18-27.

Teo, Thompson S.H., Paul Devadoss, and Shan L. Pan. 2006. Towards a Holistic Perspective of Customer Relationship Management (CRM) Implementation: A Case Study of the Housing and Development Board, Singapore. Decision Support Systems 42 (3): 1613-1627. https://doi.org/10.1016/j.dss.2006.01.007.

Terho, Harri, and Anne Jalkala. 2017. Customer Reference Marketing: Conceptualization, Measurement and Link to Selling Performance. Industrial Marketing Management 64: 175-186. https://doi.org/10.1016/j. indmarman.2017.01.005.

Thakur, Ramendra, and Letty Workman. 2016. Customer Portfolio Management (CPM) for Improved Customer Relationship Management (CRM): Are Your Customers Platinum, Gold, Silver, or Bronze? Journal of Business Research 69 (10): 4095-4102. https://doi.org/10.1016/j.jbusres.2016.03.042.

Trainor, Kevin J., James (Mick) Andzulis, Adam Rapp, and Raj Agnihotri. 2014. Social Media Technology Usage and Customer Relationship Performance: A Capabilities-Based Examination of Social CRM. Journal of Business Research 67 (6): 1201-1208. https://doi.org/10.1016/j.jbusres.2013.05.002.

Van Den Bulte, Christophe, Emanuel Bayer, Bernd Skiera, and Philipp Schmitt. 2018. How Customer Referral Programs Turn Social Capital into Economic Capital. Journal of Marketing Research 55 (1): 132-146. https://doi. org/10.1509/jmr.14.0653.

Vargo, Stephen L., and Robert F. Lusch. 2004. Evolving to a New Dominant Logic for Marketing. Journal of Marketing 68 (1): 1-17.

- 2008. Service-Dominant Logic: Continuing the Evolution. Journal of the Academy of Marketing Science 36 (1): 1-10. https://doi.org/10.1007/ s11747-007-0069-6. 
2016. Institutions and Axioms: An Extension and Update of ServiceDominant Logic. Journal of the Academy of Marketing Science 44 (1): 5-23. https://doi.org/10.1007/s11747-015-0456-3.

Vella, Joseph, and Albert Caruana. 2012. Encouraging CRM Systems Usage: A Study Among Bank Managers. Management Research Review 35 (2): 121-133. https://doi.org/10.1108/01409171211195152.

Virtanen, Tatu, Petri Parvinen, and Minna Rollins. 2015. Complexity of Sales Situation and Sales Lead Performance: An Empirical Study in Business-toBusiness Company. Industrial Marketing Management 45: 49-58. https:// doi.org/10.1016/j.indmarman.2015.02.024.

Wagner, Janet, and Sabine Benoit (née Moeller). 2015. Creating Value in Retail Buyer-Vendor Relationships: A Service-Centered Model. Industrial Marketing Management 44: 166-179. https://doi.org/10.1016/j. indmarman.2014.10.013.

Wąsowska, Aleksandra, and Marcin Pawłowski. 2011. Metody pomiaru społecznej odpowiedzialności biznesu - przegląd literatury. Przegląd Organizacji 11: 14-17. https://doi.org/10.33141/po.2011.11.4.

Waterman, Robert, Thomas J. Peters, and Julien R. Phillips. 1980. Structure Is Not Organization. Business Horizons 23 (3): 14-26.

Wendler, Roy. 2012. The Maturity of Maturity Model Research: A Systematic Mapping Study. Information and Software Technology, Special Section on Software Reliability and Security, 54 (12): 1317-1339. https://doi. org/10.1016/j.infsof.2012.07.007.

Wirtz, Jochen, and Christopher H. Lovelock. 2016. Services Marketing: People, Technology, Strategy. 8th ed. Hackensack: World Scientific Publishing Company. Wirtz, Jochen, Anouk den Ambtman, Josée Bloemer, Csilla Horváth, B. Ramaseshan, Joris van de Klundert, Zeynep Gurhan Canli, and Jay Kandampully. 2013. Managing Brands and Customer Engagement in Online Brand Communities. Edited by Lerzan Aksoy, Allard van Riel, and Jay Kandampully. Journal of Service Management 24 (3): 223-244. https://doi. org/10.1108/09564231311326978.

Xia, Lan, and Monika Kukar-Kinney. 2014. For Our Valued Customers Only: Examining Consumer Responses to Preferential Treatment Practices. Journal of Business Research 67 (11): 2368-2375. https://doi.org/10.1016/j. jbusres.2014.02.002.

Yu, Tianyuan, and NengQuan Wu. 2009. A Review of Study on the Competing Values Framework. International Journal of Business and Management 4 (7): p37. https://doi.org/10.5539/ijbm.v4n7p37.

Zaglia, Melanie E. 2013. Brand Communities Embedded in Social Networks. Journal of Business Research, Thought Leadership in Brand Management II, 66 (2): 216-223. https://doi.org/10.1016/j.jbusres.2012.07.015.

Zand, Jafar Danesh, Abbas Keramati, Farzaneh Shakouri, and Hamid Noori. 2018. Assessing the Impact of Customer Knowledge Management on 
Organizational Performance. Knowledge and Process Management 25 (4): 268-278. https://doi.org/10.1002/kpm.1585.

Zerbino, Pierluigi, Davide Aloini, Riccardo Dulmin, and Valeria Mininno. 2018. Big Data-Enabled Customer Relationship Management: A Holistic Approach. Information Processing of Management 54: 818-846. https://doi. org/10.1016/j.ipm.2017.10.005.

Zhang, Wanrong, and Sujit Banerji. 2017. Challenges of Servitization: A Systematic Literature Review. Industrial Marketing Management 65: 217-227. https:// doi.org/10.1016/j.indmarman.2017.06.003.

Zhang, Mingli, Lingyun Guo, Mu Hu, and Wenhua Liu. 2017. Influence of Customer Engagement with Company Social Networks on Stickiness: Mediating Effect of Customer Value Creation. International Journal of Information Management 37 (3): 229-240. https://doi.org/10.1016/j. ijinfomgt.2016.04.010.

Zhang, Tingting, Can Lu, Edwin Torres, and Po-Ju Chen. 2018. Engaging Customers in Value Co-Creation or Co-Destruction Online. Journal of Services Marketing 32 (1): 57-69. https://doi.org/10.1108/JSM-01-2017-0027.

Open Access This chapter is licensed under the terms of the Creative Commons Attribution 4.0 International License (http://creativecommons.org/licenses/ by $/ 4.0 /$ ), which permits use, sharing, adaptation, distribution and reproduction in any medium or format, as long as you give appropriate credit to the original author(s) and the source, provide a link to the Creative Commons licence and indicate if changes were made.

The images or other third party material in this chapter are included in the chapter's Creative Commons licence, unless indicated otherwise in a credit line to the material. If material is not included in the chapter's Creative Commons licence and your intended use is not permitted by statutory regulation or exceeds the permitted use, you will need to obtain permission directly from the copyright holder.

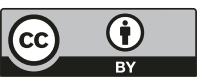

